\title{
THE POLISHED STONE INDUSTRY FROM ŞOIMUŞ - LA AVICOLA (FERMA 2), HUNEDOARA COUNTY
}

\author{
Cristian Eduard ȘTEFAN ${ }^{a}$, Mădălina DIMACHE ${ }^{b}$, Răzvan PETCUa, Dan PALCUc \\ a "Vasile Pârvan" Institute of Archaeology, Bucharest; e-mail: cristarh_1978@yahoo.com, razvan.arheo@gmail.com \\ ${ }^{b}$ Museum of the Gumelniţa Civilization, Olteniţa; e-mail: dimachemadalina@yahoo.com \\ ${ }^{c}$ Fort Hoofddijk Paleomagnetic Lab, Utrecht University; e-mail: dan.palcu@ymail.com
}

\begin{abstract}
Keywords: Turdaș, Neolithic, Şoimuş, technology, typology, polished stone industry
Abstract: In this contribution the polished stone artefacts from the Neolithic settlement at Soimus - La Avicola (Ferma 2), Hunedoara County are analysed. These items belong to Turdas facies and were discovered during rescue excavations on the A1 Motorway route in 2011. The items are analysed from the point of view of their typology, technology and context, but also their dimensions and the possible sources of raw materials being taken into consideration. A wide range of raw materials for making stone tools at Şoimuş was used, which proves the amazing adaptability of the Turdaş communities to the local environment.
\end{abstract}

Cuvinte-cheie: Turdaș, neolitic, Şoimuș, tehnologie, tipologie, industrie litică şlefuită

Rezumat: În această contribuţie ne propunem să analizăm artefactele din piatră şlefuită din aşezarea neolitică de la Şoimuş - La Avicola (Ferma 2), județul Hunedoara. Ele aparţin aspectului cultural Turdaş şi au fost descoperite în timpul săpăturilor arheologice preventive de pe traseul Autostrăzii A1 în anul 2011. Obiectele sunt analizate din punct de vedere al tipologiei, tehnologiei şi contextului lor, a parametrilor dimensionali dar şi a posibilelor puncte din care materia primă necesară producerii lor ar fi fost colectată. Materiile prime utilizate în confecționarea obiectelor din piatră şlefuită de la Şoimuş sunt foarte diverse, acest lucru dovedind uimitoarea adaptabilitate a comunitătilor turdăşene la mediul înconjurător.

\section{INTRODUCTION}

In 2011, during the construction of A1 Motorway, on the segment between Deva and Orăştie, a joint team of archaeologists from the "Vasile Pârvan" Institute of Archaeology (Bucharest), Roman and Dacian Civilization Museum (Deva), and Romanian National History Museum (Bucharest) carried out rescue excavations for three months (August-November) in the settlement of Şoimuş, (Dobrescu et alii 2016; Mărgărit et alii 2016, in press; Niţă et alii 2015; Ştefan 2014; Ştefan, Petcu 2015; Ştefan et alii 2013; 2015). The site is positioned between Şoimuş and Bălata villages, Hunedoara County, in a place called $L a$ Avicola (Ferma 2), on the middle sector of the first terrace of the Mureş River (Figs. 1 and 2). The area of the site is of ca. 70 ha, but only a small part affected by the Motorway route was investigated. Over 700 features were documented, most of them belonging to Turdaş culture, but also to Early Neolithic, Bronze Age, Middle Iron Age, Roman and Early Middle Age.

In this presentation, we analyse a number of 200 polished stone artefacts from this settlement which belongs to Turdaş cultural aspect. The range of types for these artefacts is diverse (axes, chisels, adzes, armlets, etc.) and they were discovered in different contexts (dwellings, hovels, pits, ditches). We also tried to establish the traces of use and the types of rocks collected by the community of Şoimuş.

\section{TYPOLOGY AND TECHNOLOGY}

Considering the typology, we have of the following items at Şoimuş: axes, adzes, chisels, bracelets, polishers, perforated items, bolts, a grinding mortar, a button, a shuttle and a mace head, summarising a number of 200 items. We have also a category of items (damaged or broken) which can hardly be attributed to any type (Fig. 3).

Axes (Pls. I and II) are divided in two main categories, perforated and unperforated, with a single piece from the first one (PI. II/4) and the majority from the latter. Some of the damaged axes are reused later as adzes (PI. III/2). Some of the axes are rectangular in shape, others trapezoidal and in longitudinal section they are triangular, rectangular or bulged. Experimental studies have shown the way in which wooden handles were fastened proving an impressive viability (Matheiu, Meyer 1997). 


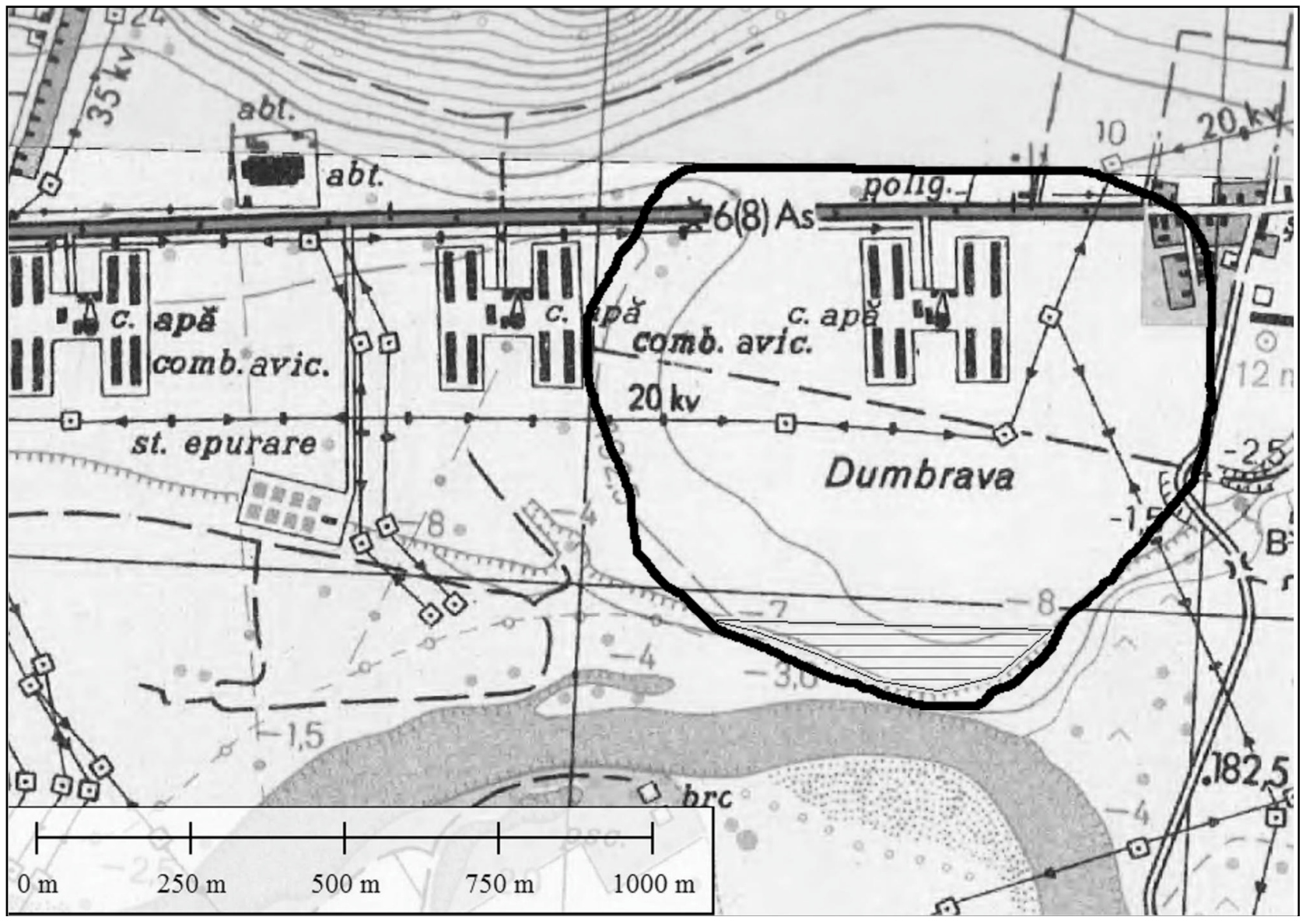

Figure 1. The topographic position of the Şoimuş - La Avicola (Ferma 2) settlement.

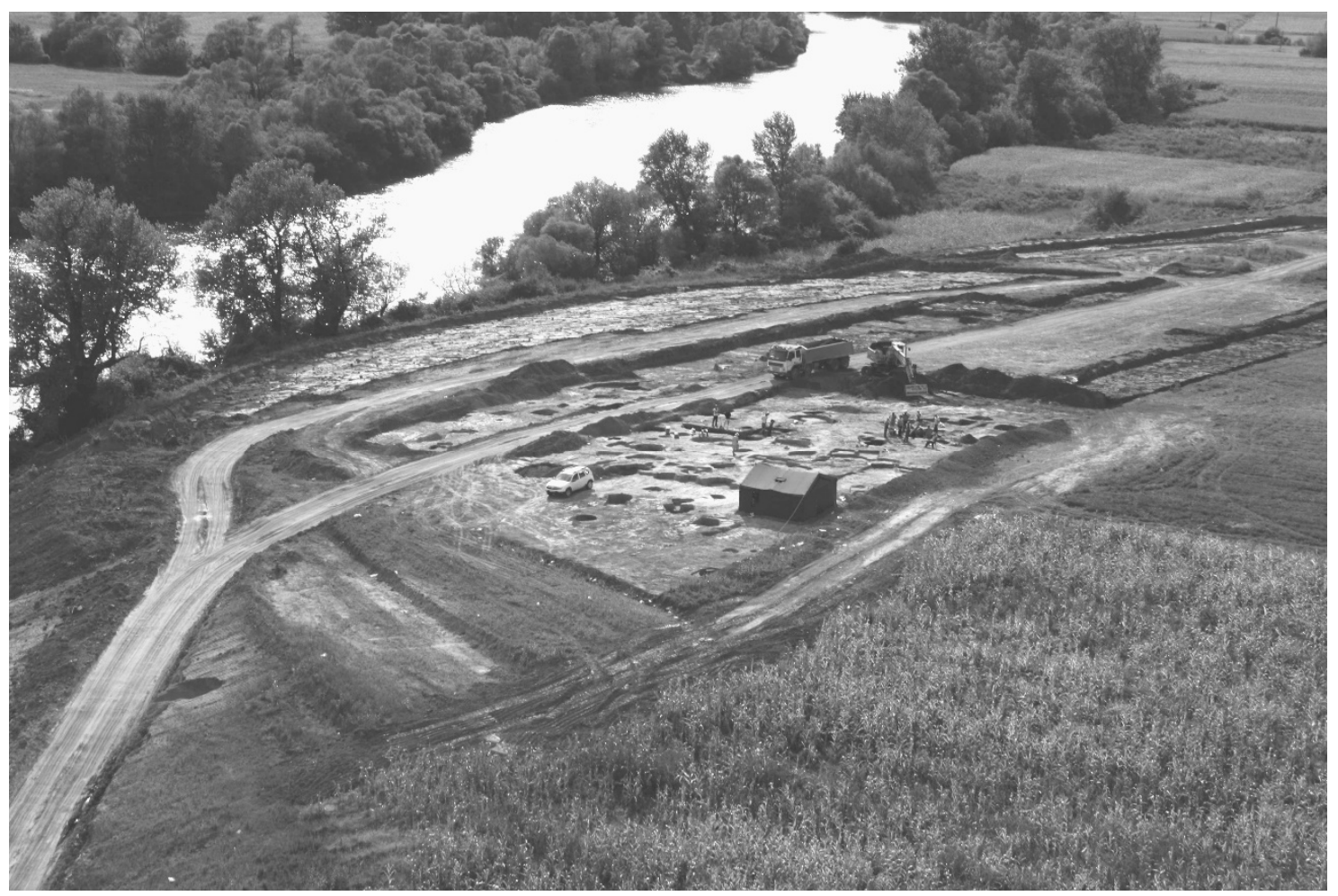

Figure 2. Aerial view of the settlement during excavations (courtesy of Carmen Bem). 


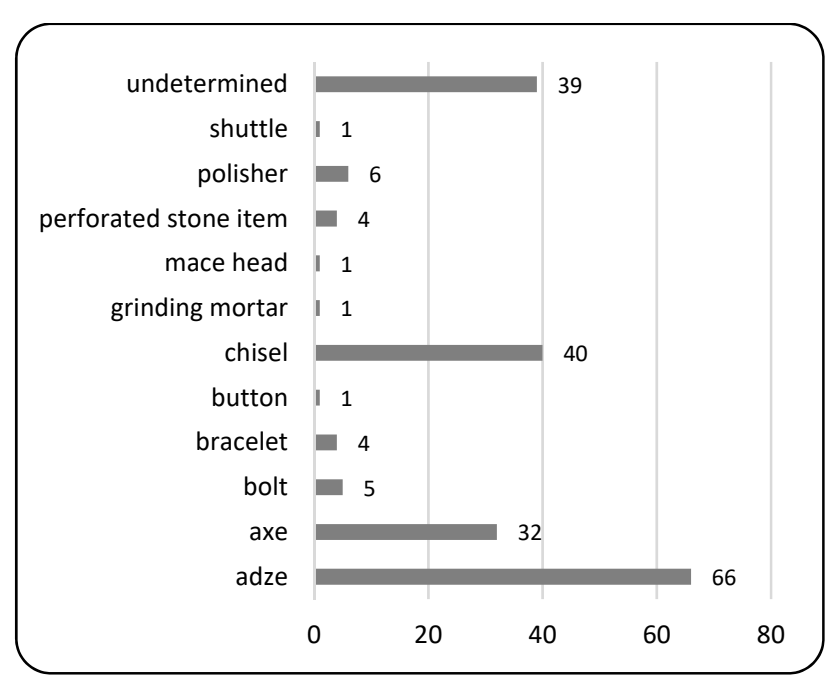

Figure 3. Typology of the polished stone items.

Adzes (Pls. III-V) are easy to recognize by the blade shape: in section is convex on one side and straight on the other side, with an angle of approx. $45^{\circ}$. They are generally trapezoidal in shape and were used probably in wood working, after taking down the trees with axes. Some wooden plank imprints from the adobe recovered in excavations show the evolved stage of wood working in the Neolithic.

Chisels (PIs. VI and VII) are different from axes by their slender figure and by their length. They were probably used also in wood working, to split the beams put under the clay floors and to obtain planks. Chisels are usually trapezoidal or rectangular in shape, some of them being damaged or broken.

Some of our items are very hard to attribute due to their broken blade (PI. VIII). They are either axes or adzes, or partially worked tools which were abandoned during the manufacturing process.

Bracelets (PI. IX/1-4) are represented by four pieces, all broken. They show heavy traces of abrasion and polishing, being uncharacteristic for the Romanian Neolithic. Another fragmentary piece of bracelet is known from Liubcova - Orniţa and it was found in a Vinča C context (Comşa 1969, p. 26, fig. 12/1). We also have six polishers ( $\mathrm{PI}$. IX/5-10), five of them with a linear groove on the side and the other one with several irregular scratches; four perforated items (PI. X/1-4), two of them rectangular and the other two circular in shape: they were probably composite pieces of the "lathes" used in the drilling process. We also identified a grinding mortar (PI. $X / 5$ ), two bolts (PI. X/6 and 7), a button (PI. X/8) and a shuttle (PI. $X / 9)$, both made of marble, and a mace head (PI. X/10).

From the preservation point of view a big part of the items are broken or damaged due to the intensive use, but we have also a good sample of whole pieces (Fig. 4). Also, it is worth mentioning that some of the cutting items (axes, adzes and chisels) have wear traces on the edge of the blade like little splints or polish.

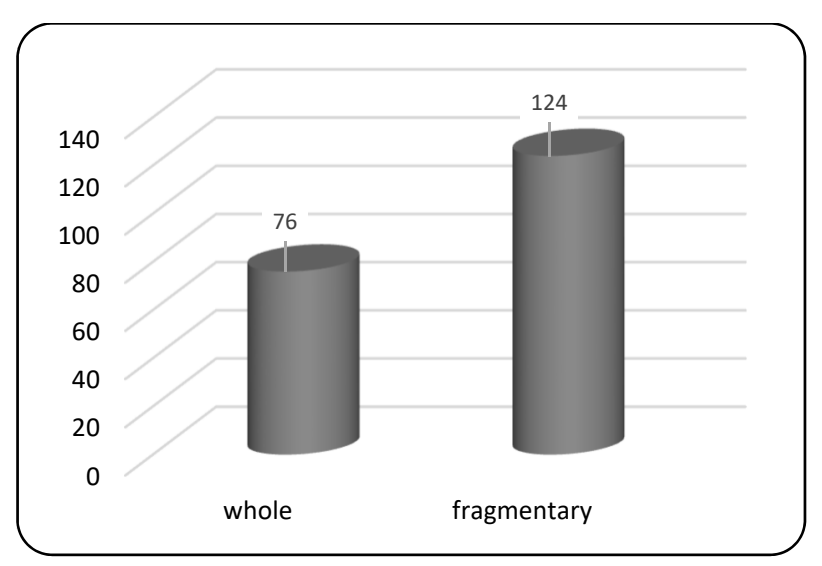

Figure 4. Preservation state of the polished stone items.

\section{RAW MATERIALS}

The Turdaş community of Şoimuş used various types of rocks (Fig. 5) from various sources (Fig. 7). We have been able to identify 30 varieties of rock with the prevalence of basalt, schist, andesite and sandstone. We also designed a possible scenario of rocks gathering by the Şoimuş community in the nearby area (Fig. 6). A recent study proved to be very useful for our discussion concerning local sources of stone used by the StarčevoCriş community from Şoimuş. Sandstone and marl were collected from the nearby terraces from Şoimuş and Bălata, being present on a larger area in the southern part of Metaliferi Mountains and in the northern part of Poiana Ruscă Mountains. Other raw materials used at Şoimuş by the Early Neolithic community (Starčevo-Criş culture) were andesite for querns and strikers and quartzite (Bărbat 2015, p. 24).

The raw materials used for making axes covered a wide range: andesite, andesitic tuff, aplite, basalt, dacitic porphyry, dacitic tuff, diorite, gneiss fragment, schist, serpentinite, siltstone and tuff. For the adzes, the range of raw materials was also wide, andesite, basalt, amphibolite, dacitic tuff, granodiorite, mudstone, quartzite, sandstone, schist and siltstone being used. As for the chisels, we documented the following rock types: andesite, basalt, gneiss fragment, dacite, diorite, granite, mudstone, rhyolite, schist, silicious mudstone and silicious siltstone. Three of the four bracelets were made of sandstone and one of siltstone; three perforated stone items were made of sandstone and the fourth of basalt. All six polishers were made of sandstone, the mace head of dioritic porphyry, the grinding mortar of phyllite and the two bolts of basalt. 


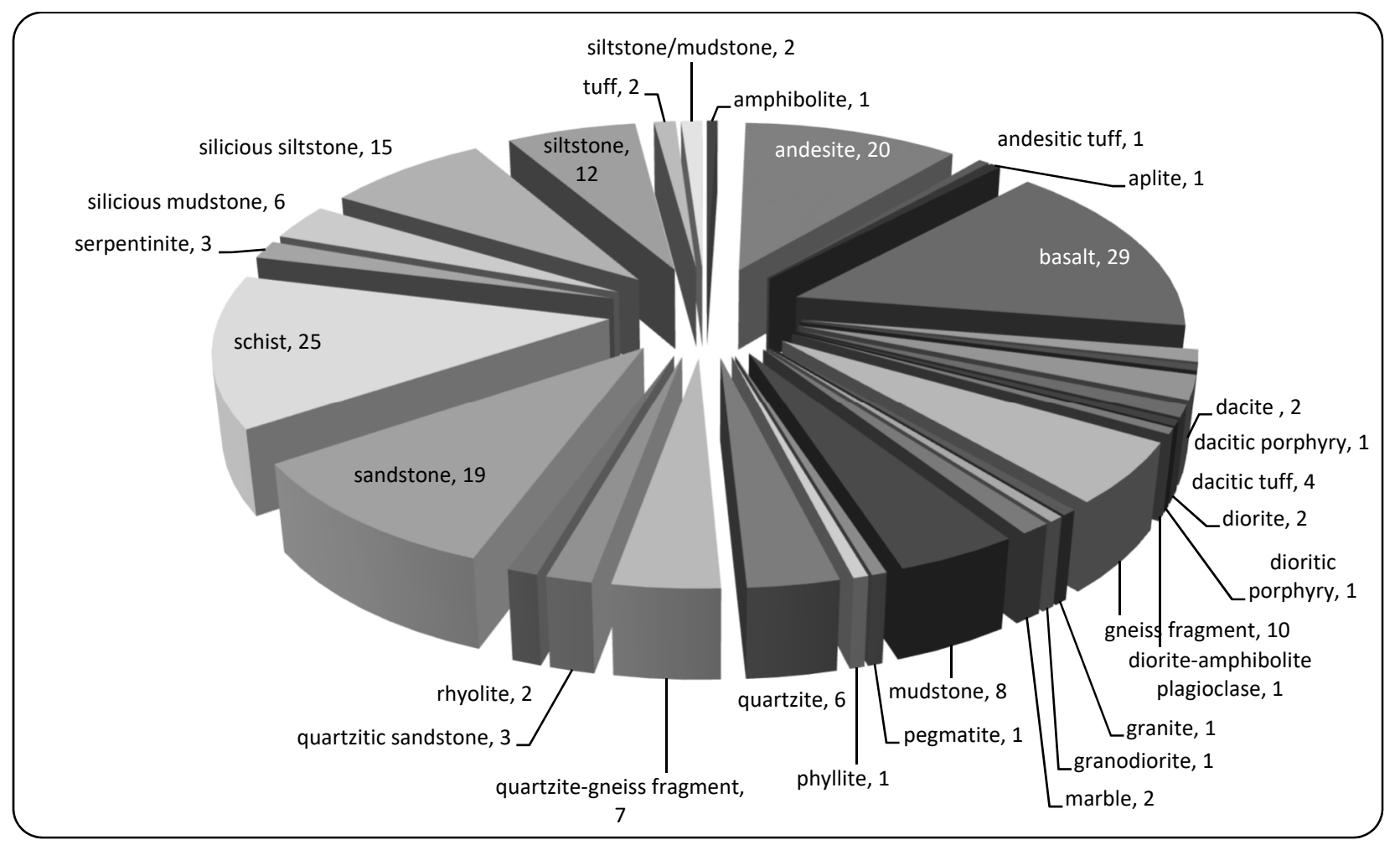

Figure 5. Rock type of the polished stone items.

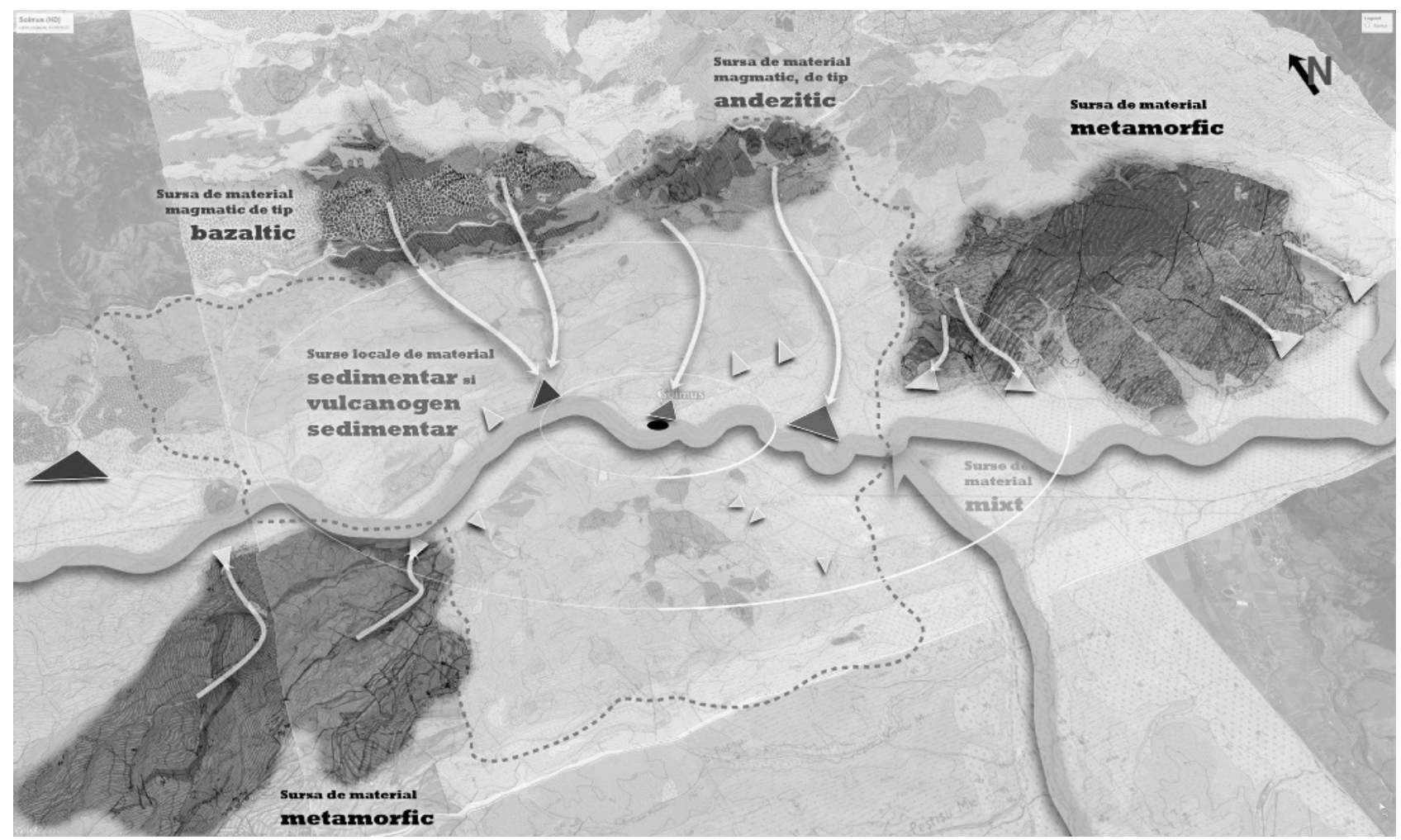

Figure 6. Possible scenario of stone gathering on the middle Mureș Valley. 


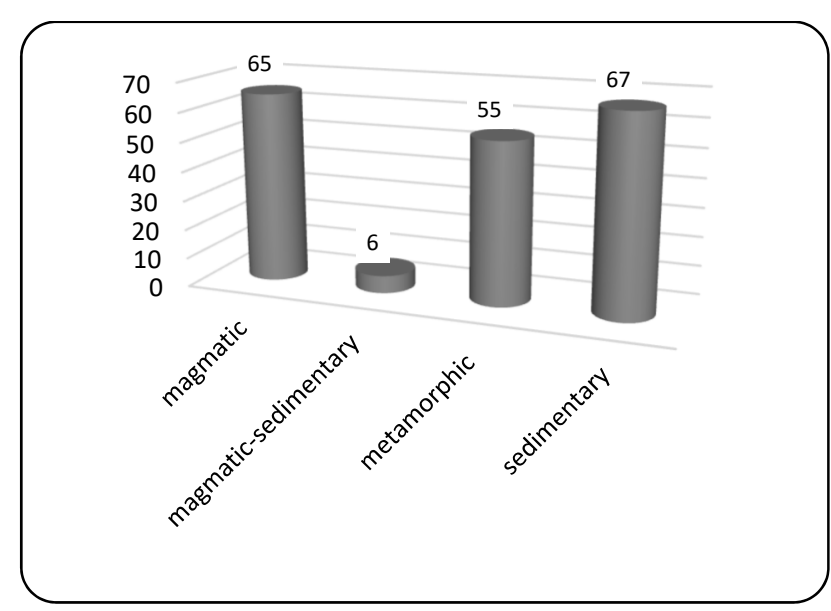

Figure 7. Rock origin of the polished stone items.

The closest source for andesite was at ca. $2 \mathrm{~km}$, on Dealul Cetăţii, near Deva, and the quartzite could be recovered from the river bed of the Mureş and its tributaries (Bărbat 2015, p. 25).

In the case of the settlement of Liubcova - Orniţa also, the analysis of raw materials showed that, at least for axes, the Neolithic community collected schists stones from the of Mehedinţi Mountains (Comşa 1969, p. 21).

\section{DIMENSIONS}

Concerning the dimensions, we choose only three categories as significant (axes, adzes and chisels) due to the high frequency of these types and we took into consideration only the complete pieces. We measured four parameters for these three categories, namely maximum length $(\mathrm{cm})$, maximum width $(\mathrm{cm})$, blade width $(\mathrm{cm})$ and weight $(\mathrm{g})$.

When we look at axes, we see a certain standardisation of their length (around $5 \mathrm{~cm}$, more or less), width (between 3 and $4 \mathrm{~cm}$ ), blade width (between 3 and $4 \mathrm{~cm}$ ) and weight (between 30 and $200 \mathrm{~g}$ ). The only exception is the big axe from PI. I/Fig. 15 which stands out comparing to the other pieces (See Figs. 8-11).

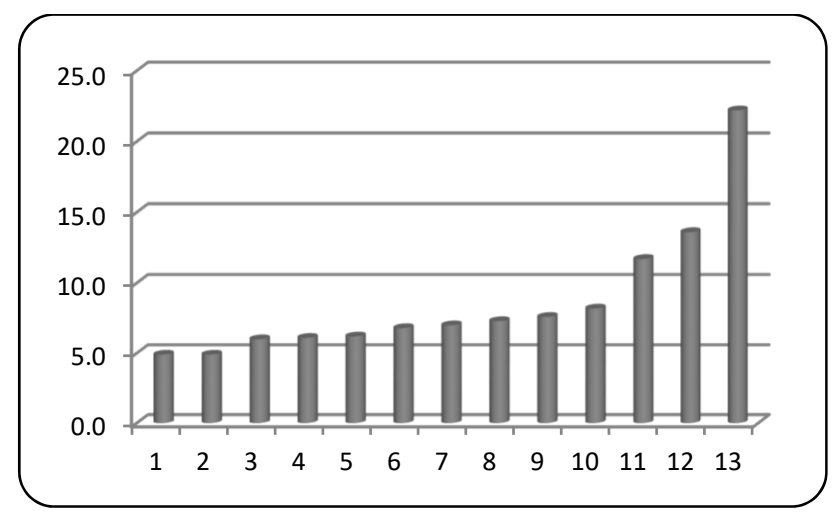

Figure 8. Axes. Maximum length of the whole pieces $(\mathrm{cm})$.

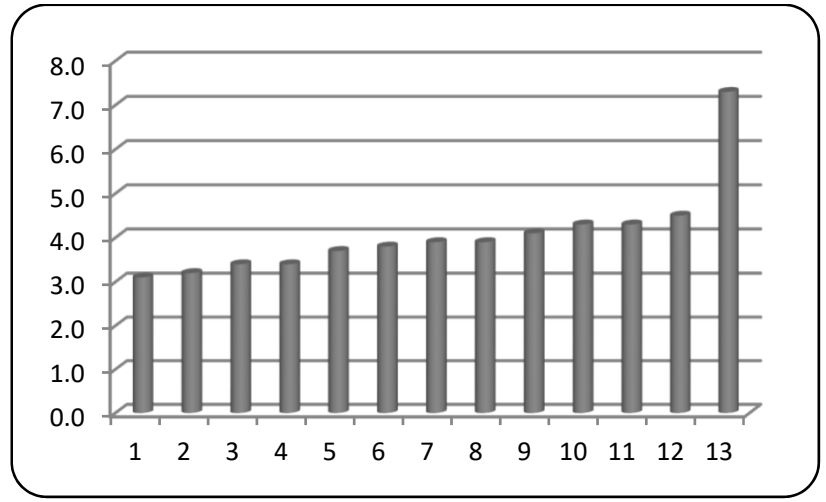

Figure 9. Axes. Maximum width of the whole pieces $(\mathrm{cm})$.

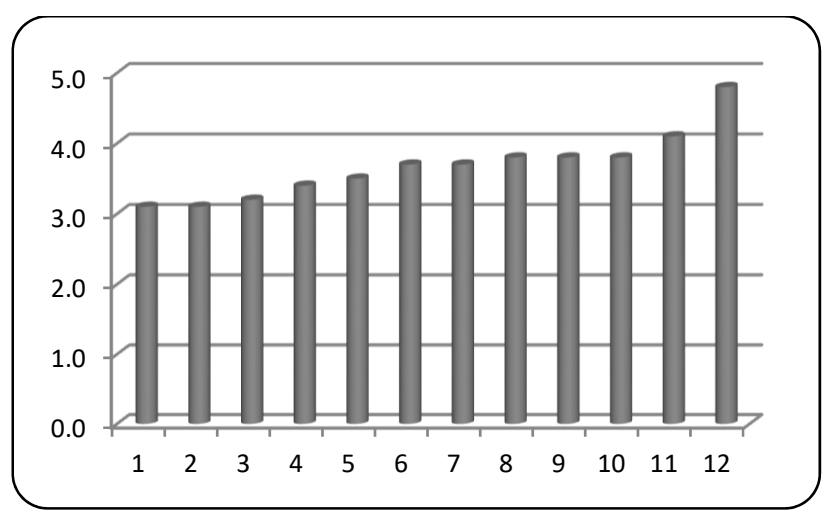

Figure 10. Axes. Blade width of the whole pieces $(\mathrm{cm})$.

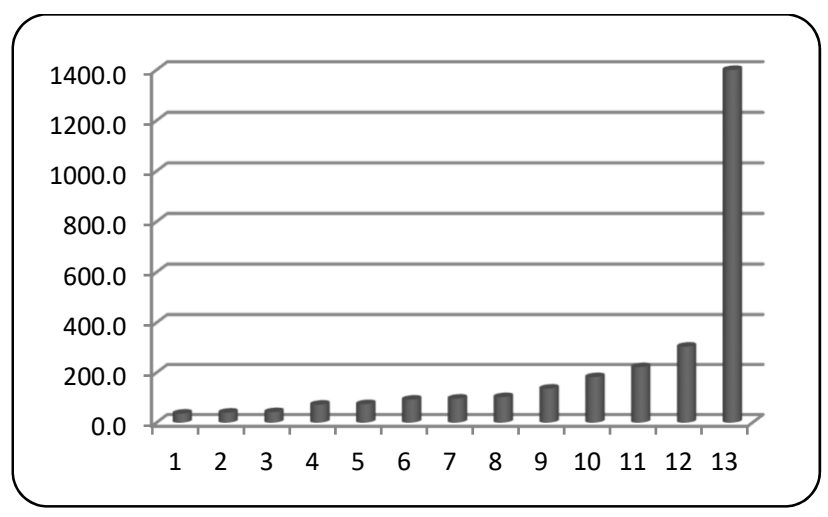

Figure 11. Axes. Weight of the whole pieces (g).

If we look at the adzes, we also see some standardisation in their maximum length (two major groups: $4-6 \mathrm{~cm}$ and $6-8 \mathrm{~cm}$, again we have an exception which stands out from the group - no. 28), maximum width (three major groups: $1-2 \mathrm{~cm}, 2-3 \mathrm{~cm}$ and $3-4 \mathrm{~cm}$ ), blade width (seven groups, a few of them with the same value see nos. 8 to 13 in Fig. 14) and weight (three major groups: less than $50 \mathrm{~g}, 50-100 \mathrm{~g}$ and $100-150 \mathrm{~g}$, with two exceptions - nos. 27 and 28). 


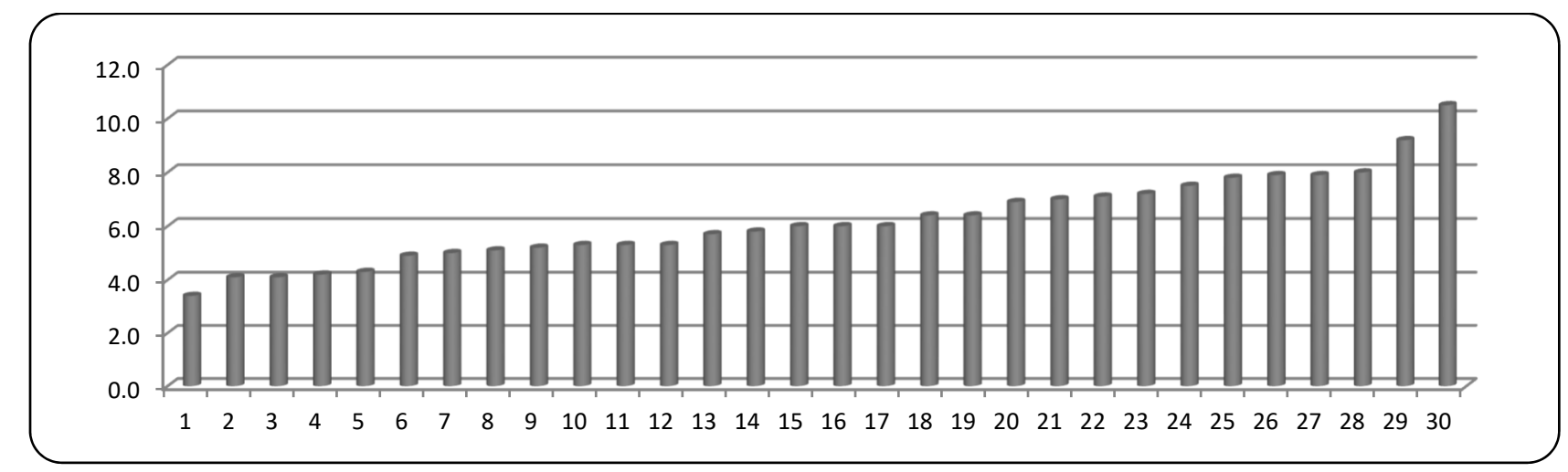

Figure 12. Adzes. Maximum length of the whole pieces $(\mathrm{cm})$.

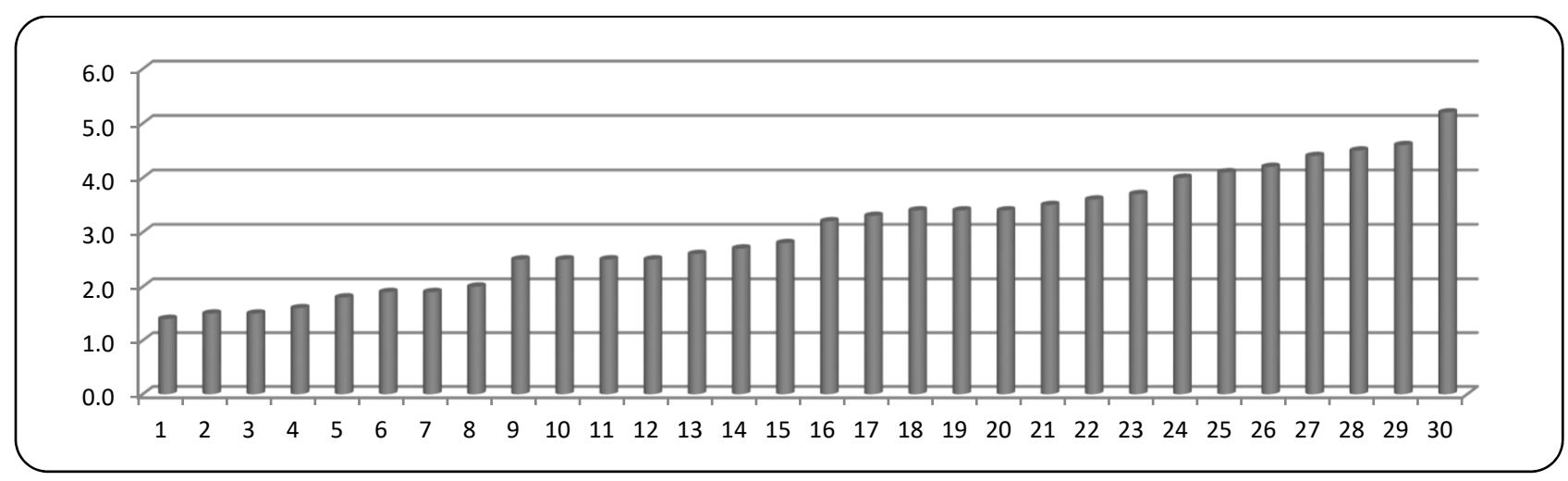

Figure 13. Adzes. Maximum width of the whole pieces (cm).

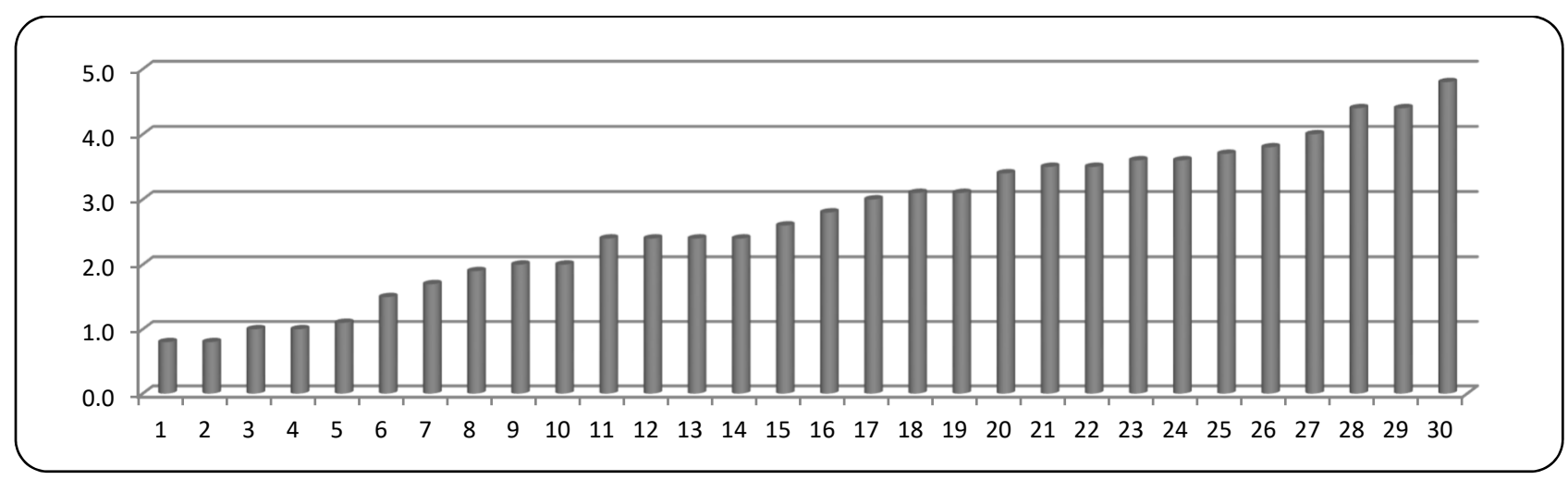

Figure 14. Adzes. Blade width of the whole pieces $(\mathrm{cm})$.

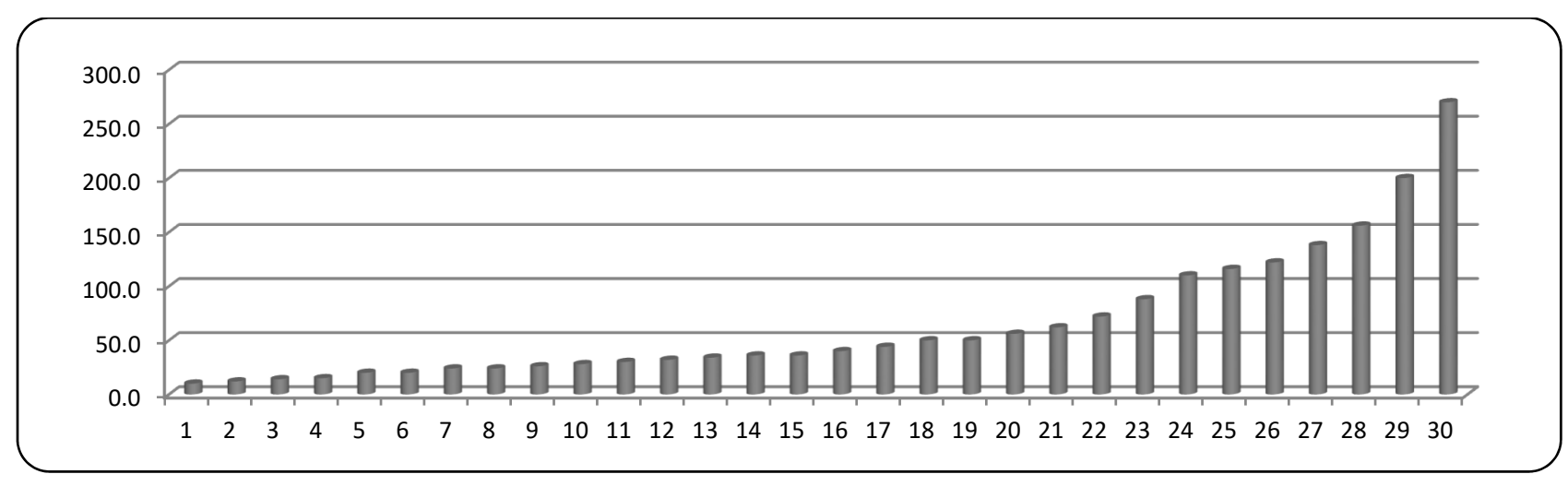

Figure 15. Adzes. Weight of the whole pieces ( $g$ ). 
The last category submitted to this kind of analysis is represented by chisels (Figs. 16-19). They are divided in two main groups in function of maximum length, $4-8 \mathrm{~cm}$ and 8-12 cm, with one exception - no. 23; concerning the maximum width we have six groups between 1.5 and 4.5 $\mathrm{cm}$. If we look at the blade width we notice three major groups between 1 and $3.5 \mathrm{~cm}$ with the exception of piece no. 23 . The last criteria used by us, the weight, divides the whole bulk of items in three major groups: less than $50 \mathrm{~g}$, 50-100 g and 100-150 g, with two exceptions - items no. 22 and 23.

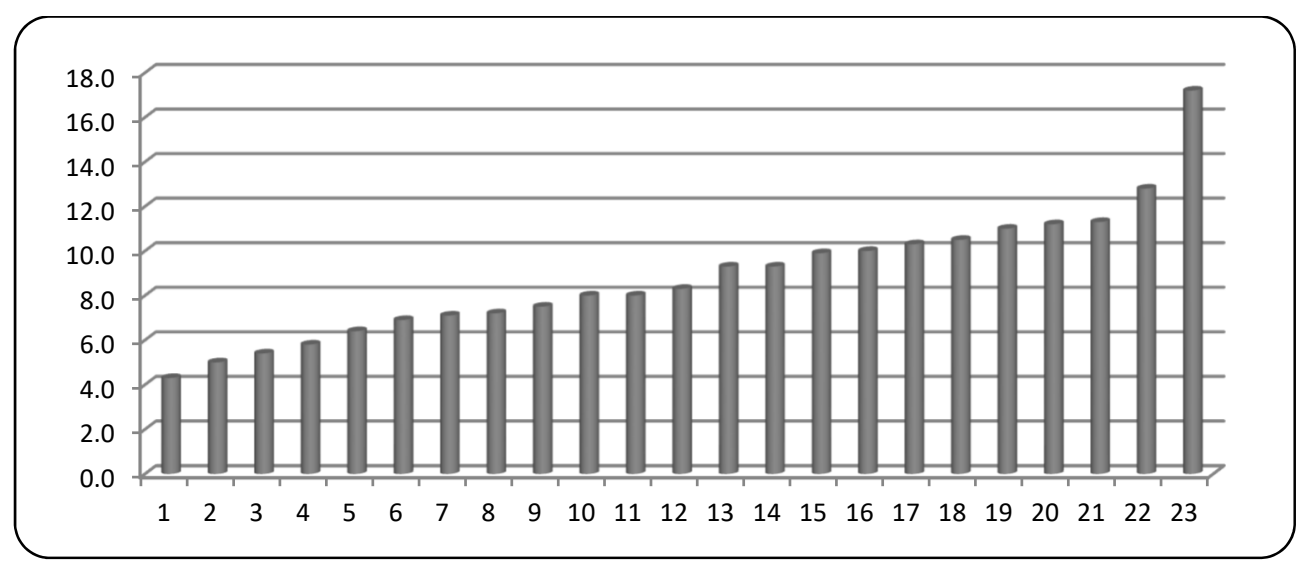

Figure 16. Chisels. Maximum length of the whole pieces $(\mathrm{cm})$.

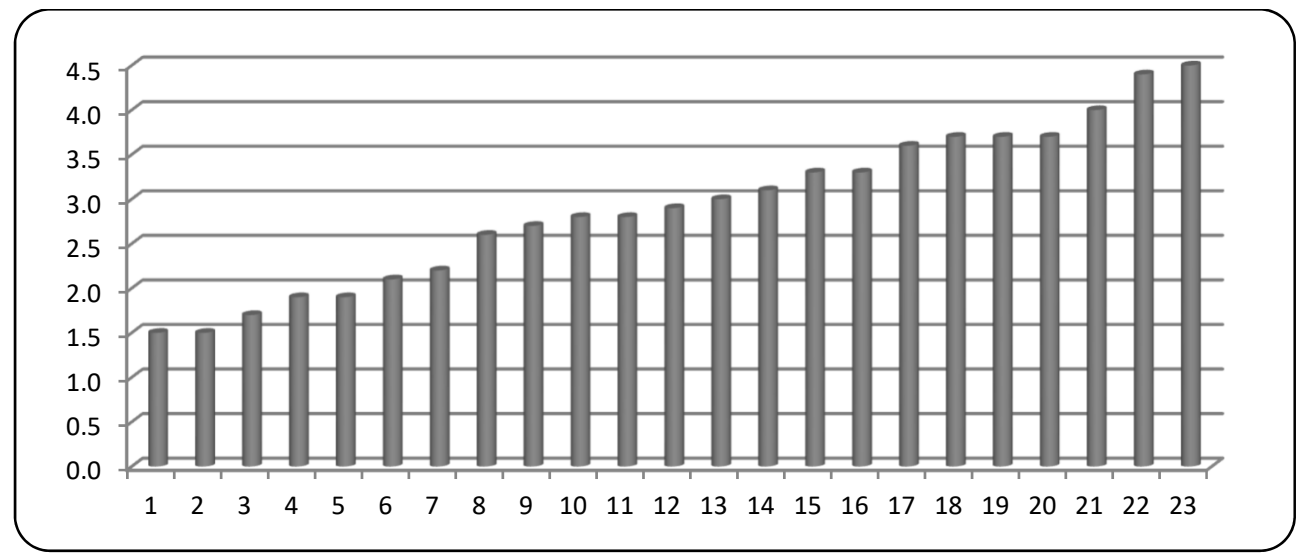

Figure 17. Chisels. Maximum width of the whole pieces $(\mathrm{cm})$.

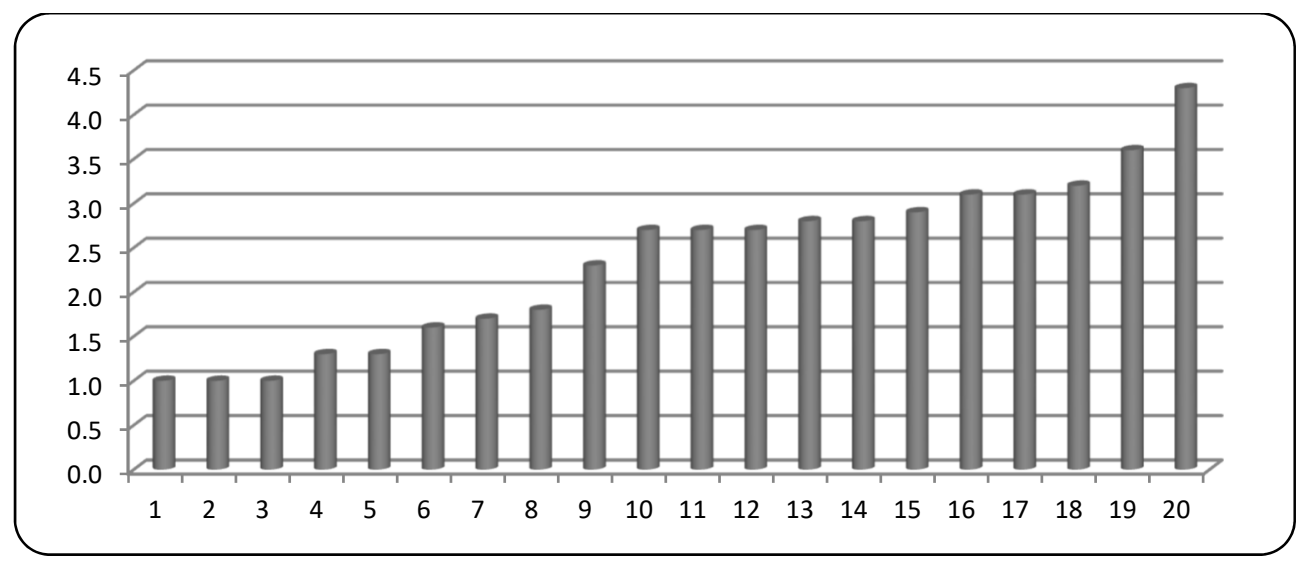

Figure 18. Chisels. Blade width of the whole pieces $(\mathrm{cm})$. 


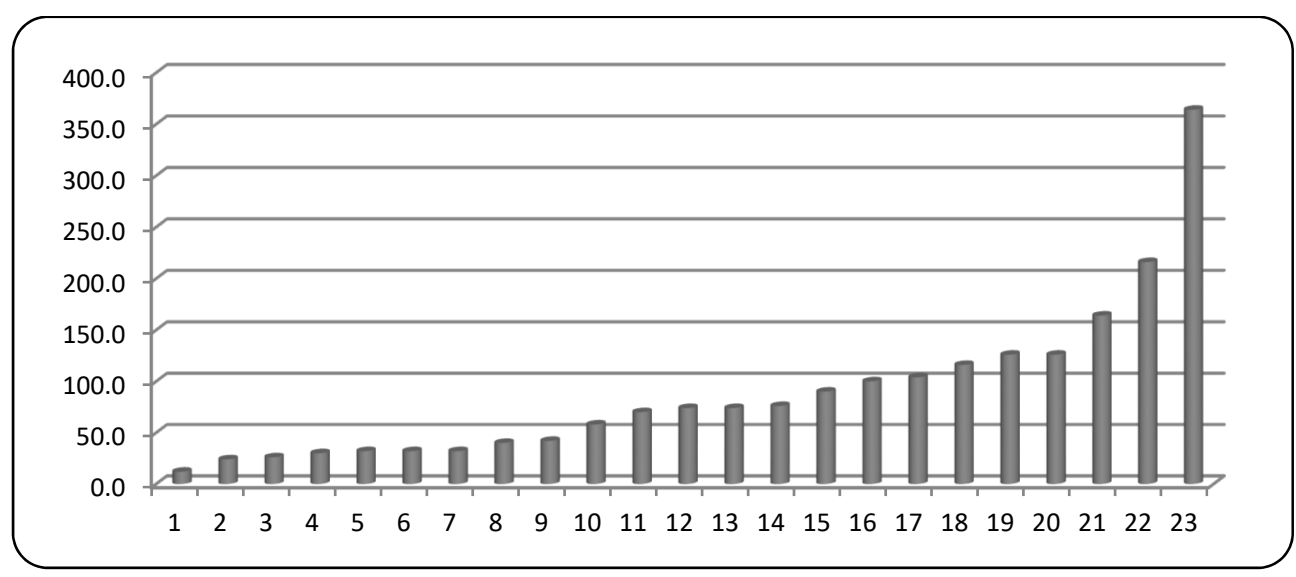

Figure 19. Chisels. Weight of the whole pieces $(\mathrm{cm})$.

\section{CONTEXT AND ANALOGIES}

Most of the polished items were recovered from pits, but they were present also in other types of features and an important part of them was recovered from the archaeological layer (Fig. 20). Generally, in every feature were found one to three items, but we also found some exceptions, such as pit $\mathbf{C} . \mathbf{2 1 0}$ with seven items, dwelling $\mathbf{L} \mathbf{2}$ with eleven items or dwelling $\mathbf{L 7}$ with six items. It is possible that the features mentioned above represented some activity areas involving polished stone items.

If we look at the contexts in which axes were found, we see that half of them came from the habitation layer (16 items), nine from pits, three from hovels and four items were recovered from surface dwellings and a ditch (two items from each context). Concerning adzes, 30 pieces were recovered from pits, 19 from the habitation layer, nine from surface dwellings, five from hovels and three from ditches. The contexts of discovery for the chisels are the following: 15 pieces from pits, 14 from the habitation layer, seven from surface dwellings (five items were recovered from Dwelling L2), three from ditches and one from a hovel. We can mark here, on the one hand, the big number of the pieces recovered from the habitation layer, and on the other hand the scarcity of the items discovered in ditches (only eight). Although we have 12 enclosing ditches at Șoimuș, only two of them (C. 237 and C. 239) contained such items, which can be interpreted as a special deposition. It is worth mentioning that these two ditches contained, amongst other artefacts, exotic items such as obsidian or human bones.

Two of the bracelets were discovered in pits, one in a hovel and one in the habitation layer. The two marble pieces have also secure contexts: the button was found in a hovel (C. 78) and the shuttle in a ditch (C. 239, see infra).
Analogies for our polished items are to be found at Turdaş - Luncă (Luca 2001, p. 51-53, Fig. 2/1, 4-7, 10-18, Fig. 3/5-7, 10, 11, 14, 15; von Roska 1941, p. 106-166, Taf. XXXI-LXI), Orăştie - Dealul Pemilor (Luca 1997, p. 36-37, PI. I/6; II/1-3, 7, 9, 11; III/23; IV/30; VI/9; XII/9; XVIII/8-11, 13; XX/4; XXV/1, 2; XLIII/5) or Tărtăria - Gura Luncii (Luca 2016, p. 216-219, foto 233-241), the latter especially for the marble pieces.

Similar stone items were also found in the Vinča settlements (phase C) from Banat (Draşovean 1996, p. 44, PI. VII-XI). In the case of the Banat settlements, distant sources were exploited, which can be deduced from the intensive use of the axes and chisels, meaning that the Neolithic communities from Banat used these stone items for a long time (Draşovean 1996, p. 44).

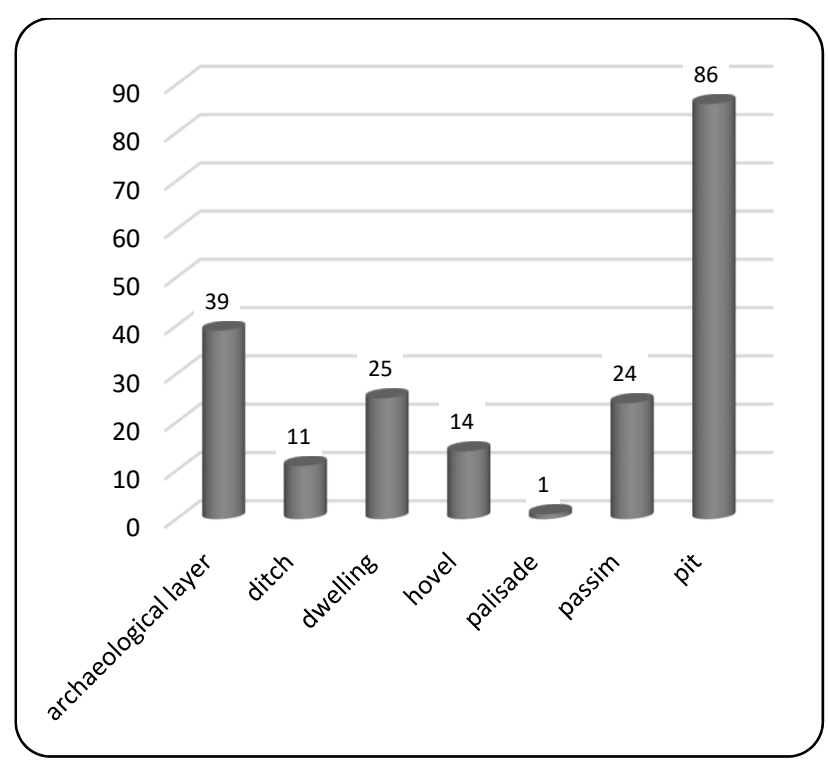

Figure 20. Contexts of the polished stone items. 


\section{CONCLUSIONS}

In this study, we tried to discuss the different types of stone used by the Neolithic community of Şoimuş for tool making. The very large range of rock types gathered by Neolithic people of Şoimuş show us their perfect adaptability at the local environment and also a dynamic exchange in the first half of the $\mathrm{V}^{\text {th }}$ millennium $B C$ in the middle Mureş area. Axes were most probably used in deforestation processes for obtaining new agricultural land and adzes with chisels in woodworking. Some of the daub fragments from surface dwellings of Şoimuş bear wood traces proving the fact that local community used worked wood in constructing dwellings (poles, beams etc.). On the other hand, most of the axes/adzes/chisels blades show use wear traces like little splints or shiny edges which prove their long utilization.

Some of the items were chosen due to their colour and aspect, being probably brought by exchange from other areas. We are thinking of the marble pieces, especially of the shuttle which certainly shows use wear traces (PI. X/9), but also the button ( $\mathrm{PI}$. $\mathrm{X} / 8$ ). For the marble pieces found at Tărtăria, the raw material is supposed to be local (Luca 2016, p. 219).

One of the interesting facts in analysing the artefacts of Şoimuş is that we don't have any copper items, but, on the other hand, we have many bone and antler tools, flint and obsidian items and polished stone artefacts. The needs of the Neolithic community of Şoimuş were fulfilled by this kind of artefacts so the copper was neglected at the beginning of the $\mathrm{V}^{\text {th }}$ millennium $\mathrm{BC}$ (here we must specify that only a small part of the settlement was excavated).

\section{REFERENCES}

Bărbat 2015 - I. A. Bărbat, Interacţiunea comunităţilor neoliticului timpuriu cu mediul înconjurător. Aşezările Starčevo-Criş de la Şoimuş (jud. Hunedoara) (I), Sargetia SN 6, 2015, p. 9-40.

Comşa 1969 - E. Comşa, Donées concernant la civilisation Vinča du sudouest de la Roumanie, Dacia NS 13, 1969, p. 11-44.

Dobrescu et alii 2016 - R. Dobrescu, C. E. Ştefan, C. Bonsall, Observations sur l'industrie en obsidienne découverte à Şoimuş-La Avicola (Ferma 2), MCA 12, 2016, p. 45-56.

Draşovean 1996 - F. Draşovean, Cultura Vinča târzie (faza C) în Banat, Timişoara, 1996.

Luca 1997 - S. A. Luca, Aşezări neolitice pe valea Mureşului (I). Habitatul turdăşean de la Orăştie-Dealul Pemilor (punct X2), Alba Iulia, 1997.

Luca 2001 - S. A. Luca, Aşezări neolitice pe valea Mureşului (II). Noi cercetări arheologice la Turdaş-Luncă. I. Campaniile anilor 19921995, Alba Iulia, 2001.

Luca 2016 - S. A. Luca, Tărtăria rediviva, Alba Iulia, 2016.

Mathieu, Meyer 1997 - J. R. Mathieu, D. A. Meyer, Comparing axe heads of stone, bronze, and steel: studies in experimental archaeology, Journal of Field Archaeology 24, 1997, 3, p. 333-351.

Mărgărit et alii 2016 - M. Mărgărit, C. E. Ştefan, V. Dumitraşcu, Exploitation strategies of animal resources in Şoimuş-La Avicola (Ferma 2) settlement (Western Romania), Documenta Praehistorica 43, 2016 (in press).

Niţă et alii 2015 - L. Niţă, C. E. Ştefan, M. Dimache, T. Hila, R. Petcu, Consideraţii privind industria litică de la Şoimuş-La Avicola (Ferma 2), jud. Hunedoara, BMJT 7, 2015, p. 97-116.

von Roska 1941 - M. von Roska, Die Sammlung Zsófia von Torma in der numismatisc-archaeologischen Abteilung des siebenbürgischen Nationalmuseums, Cluj, 1941.

Ştefan 2014 - C. E. Ştefan, Some special clay artifacts from Şoimuş-La Avicola (Ferma 2), Hunedoara County, Romania, The Old Potter's Almanack 19, 2014, 2, p. 14-22.

Ştefan, Petcu 2015 - C. E. Ştefan, R. Petcu, Scurtă notă asupra unor capace de lut cu trăsături umane de la Şoimuş-La Avicola (Ferma 2), jud. Hunedoara, SP 12, 2015, p. 117-126.

Ştefan et alii 2013 - C. E. Ştefan, R. Petcu, R. Petcu, Reprezentări antropomorfe din aşezarea neolitică de la Şoimuş-La Avicola (Ferma 2), jud. Hunedoara, SP 10, 2013, p. 49-66.

Ştefan et alii 2015 - C. E. Ştefan, R. Petcu, R. Petcu, Vase cu picioare de Ia Şoimuş-La Avicola (Ferma 2), jud. Hunedoara, SCIVA 66, 2015, 34, p. 183-209. 


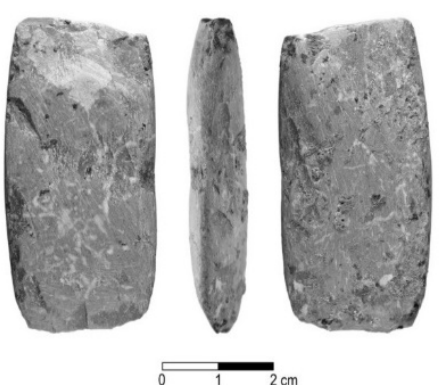

1

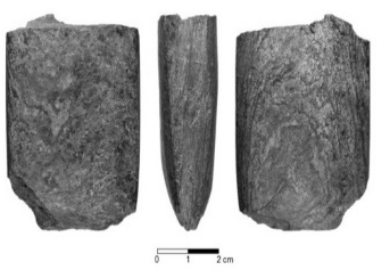

4
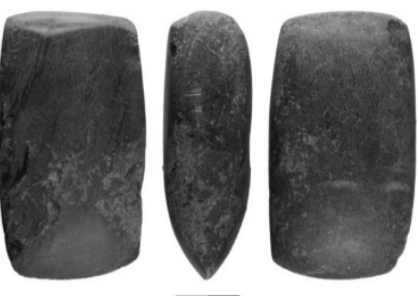

7
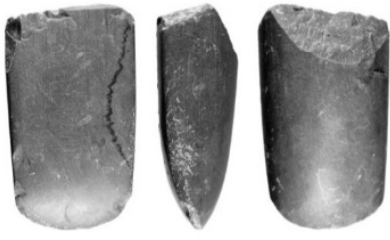

10

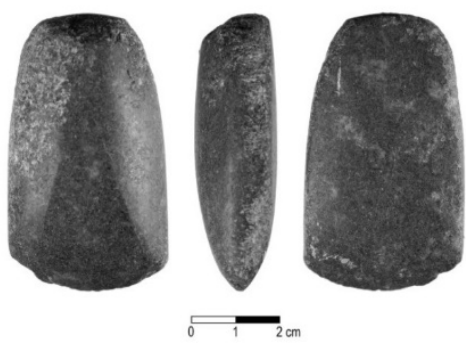

13
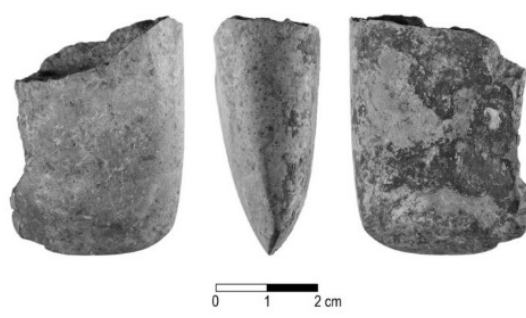

2

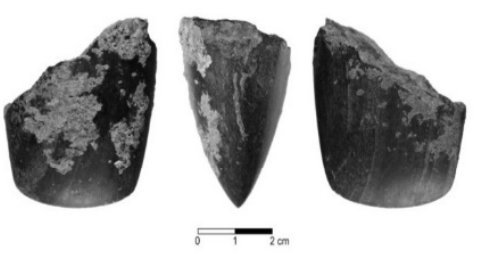

5

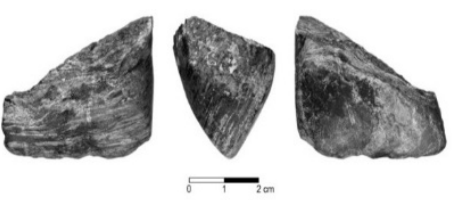

8

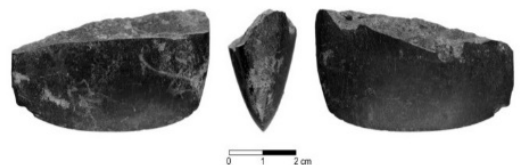

11
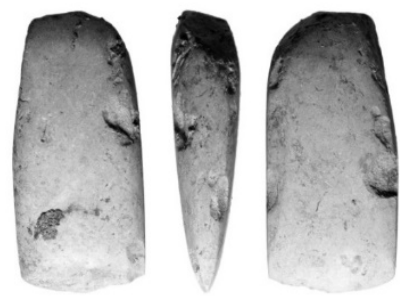

14

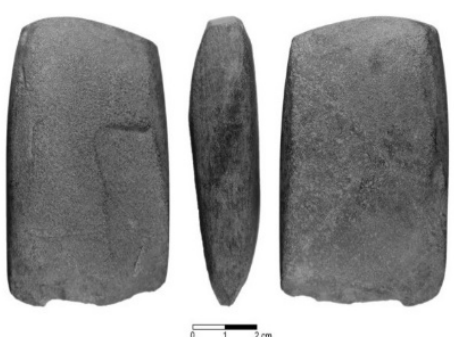

3

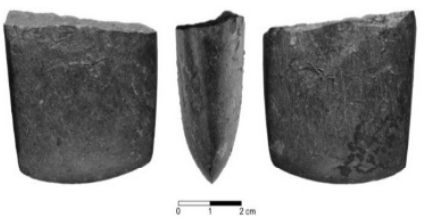

6

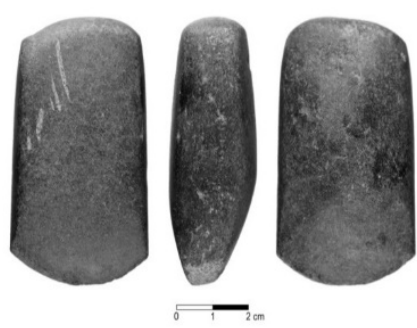

9

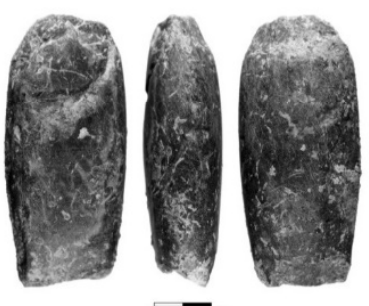

12

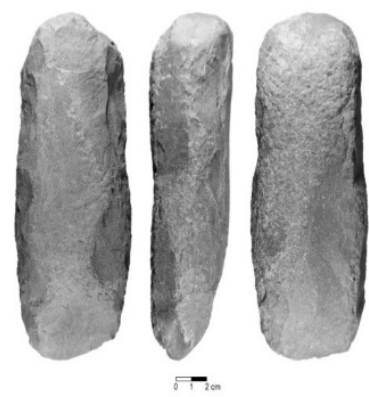

15

Plate I. Axes. 


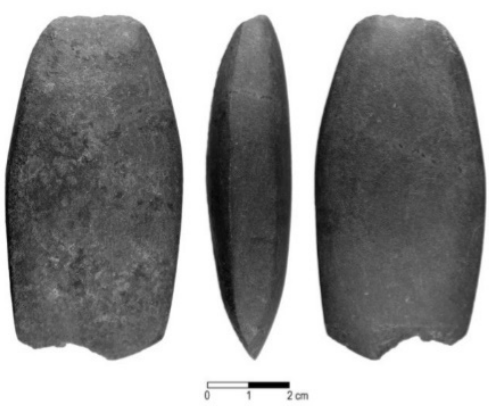

1

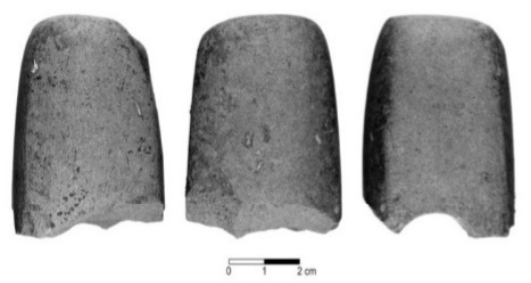

4

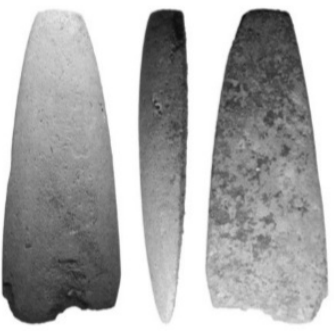

7
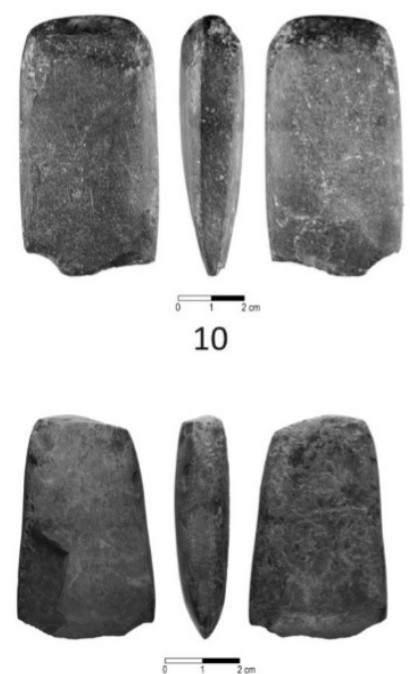

13
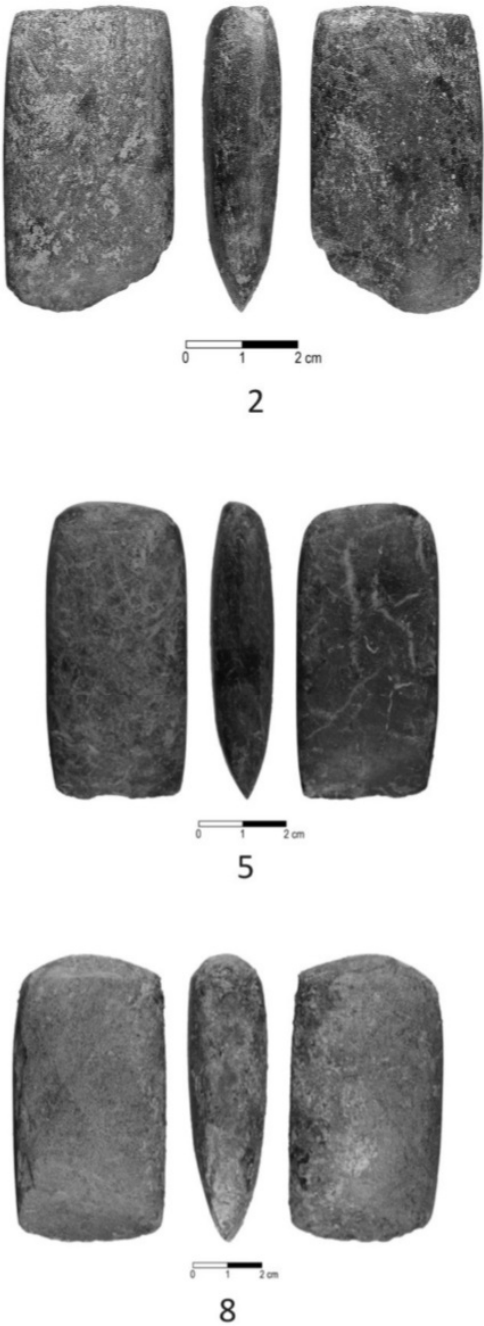

8
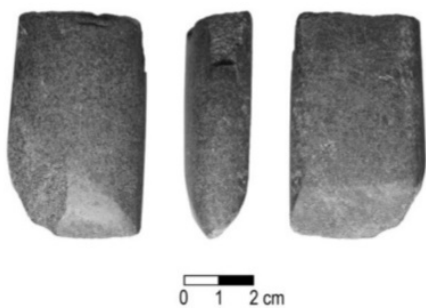

11

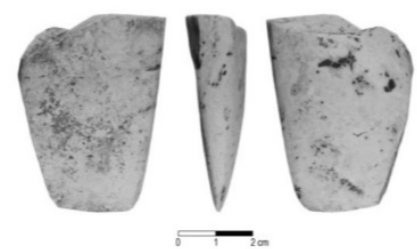

14

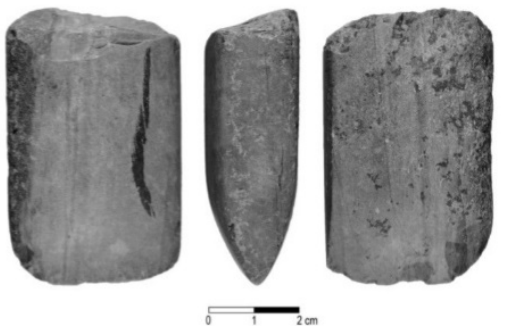

3
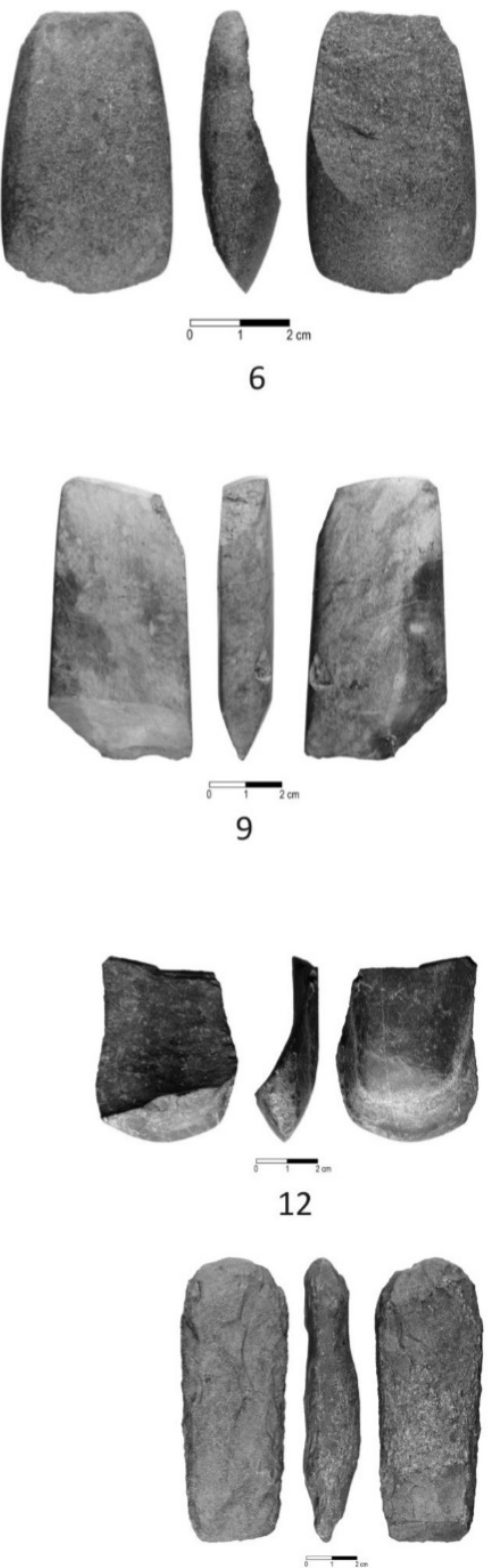

15

Plate II. Axes. 


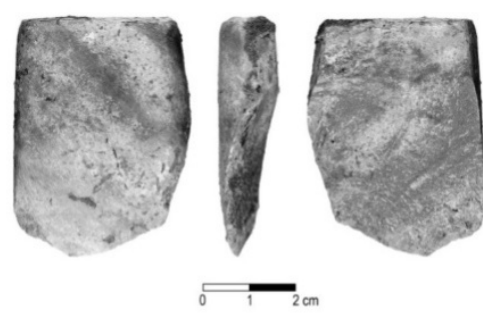

1

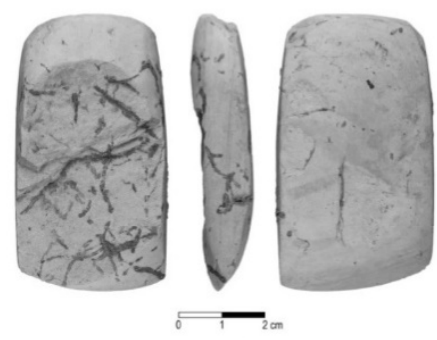

4
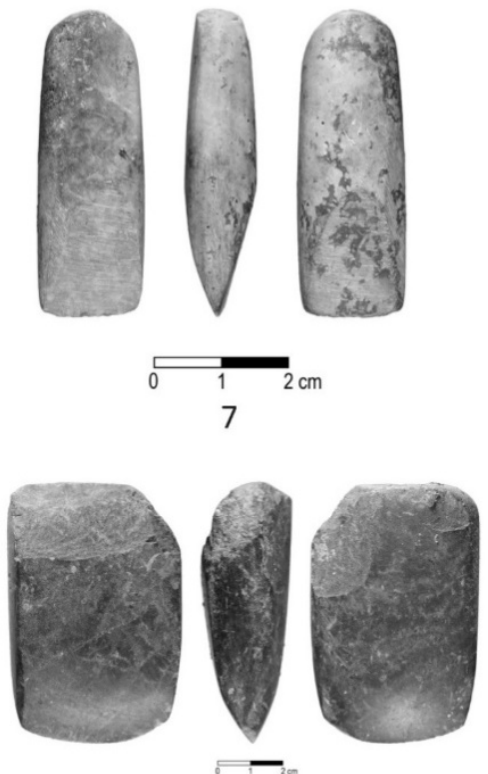

10
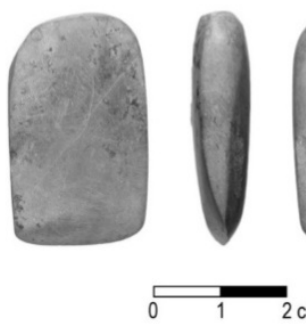

13
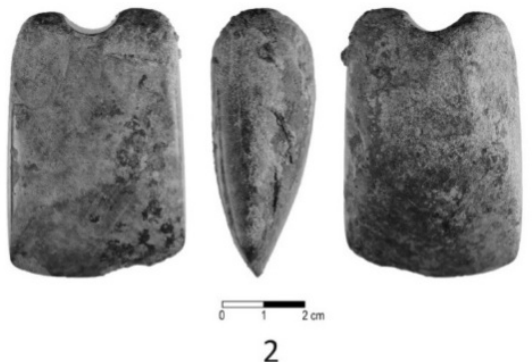

2
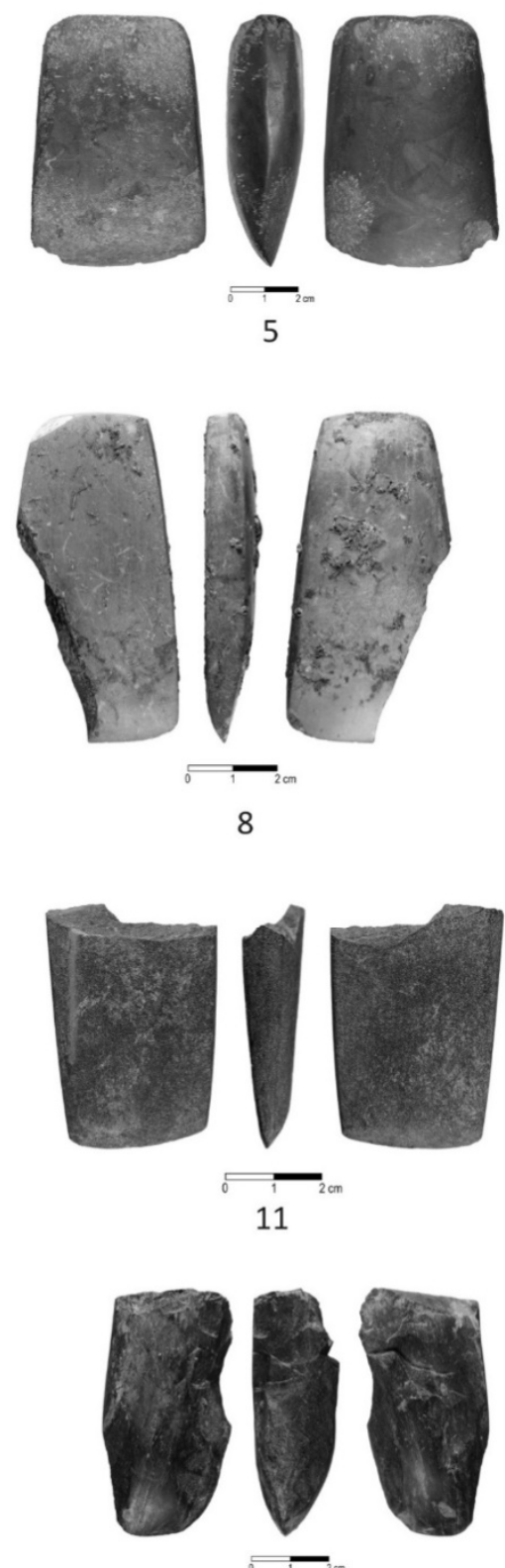

14

Plate III. Adzes.

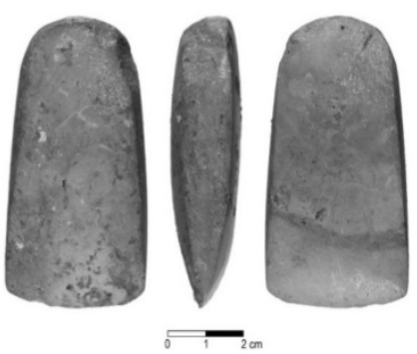

9

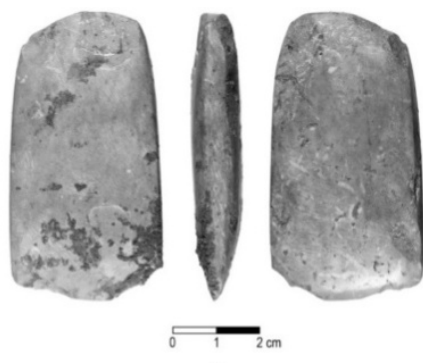

3

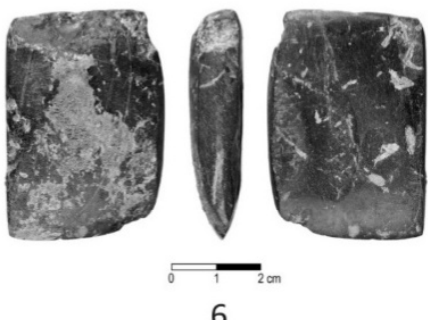

6
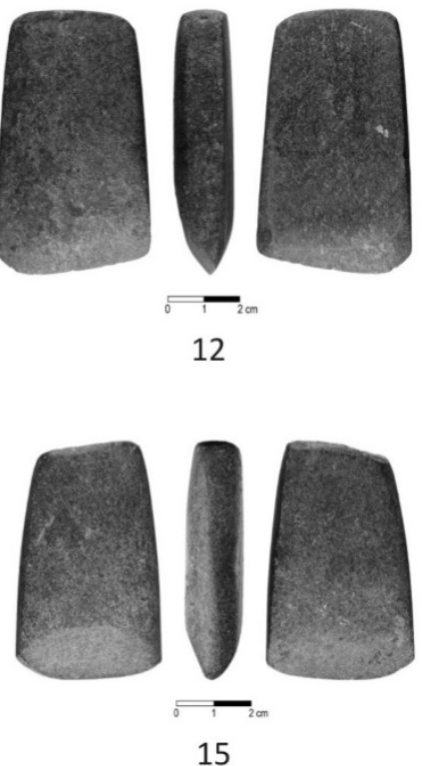


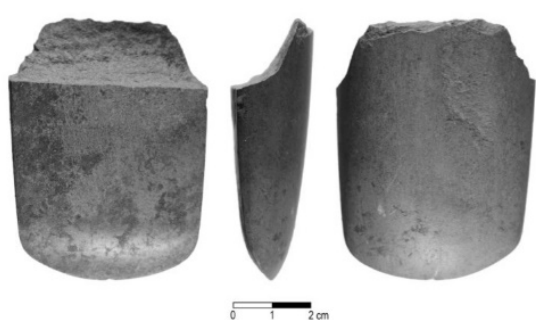

1
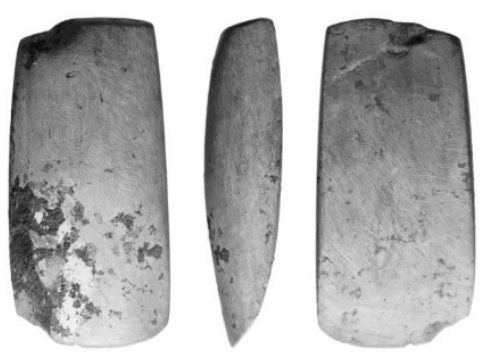

${ }_{4}^{2} \mathrm{~cm}$
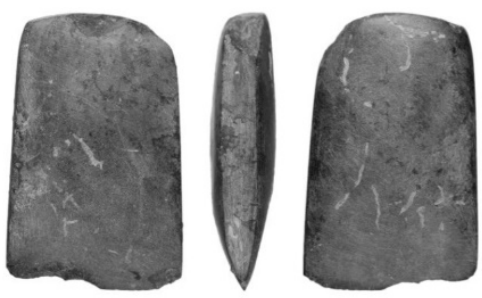

7
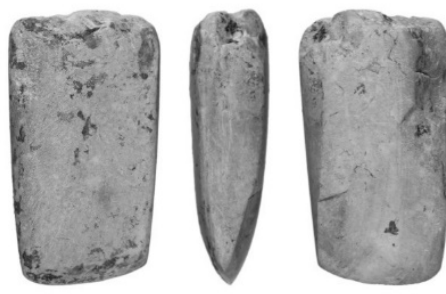

10

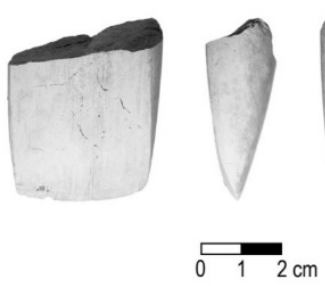

13
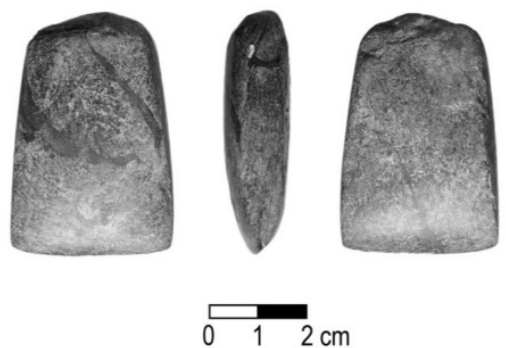

2

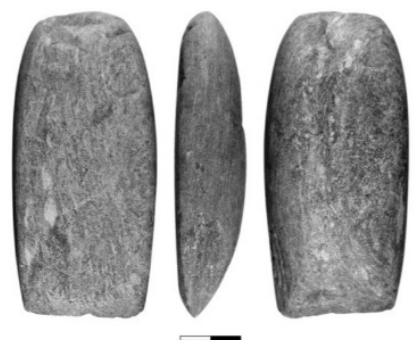

5
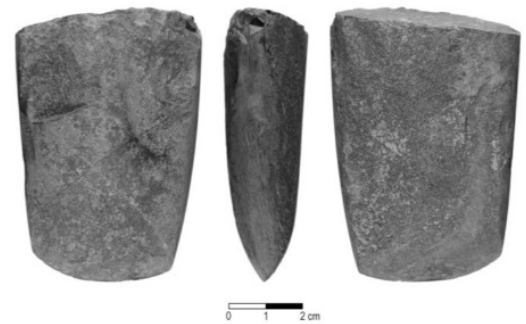

8

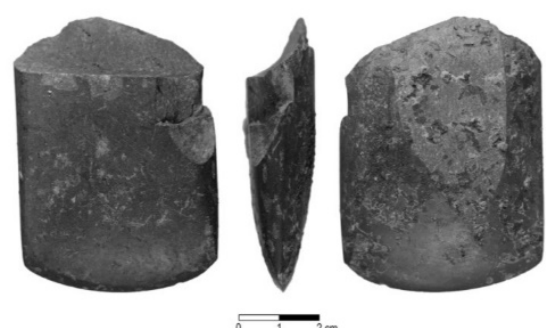

11
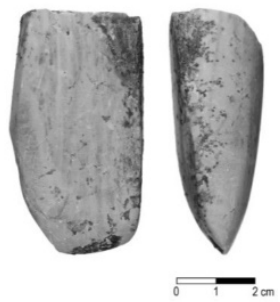

14
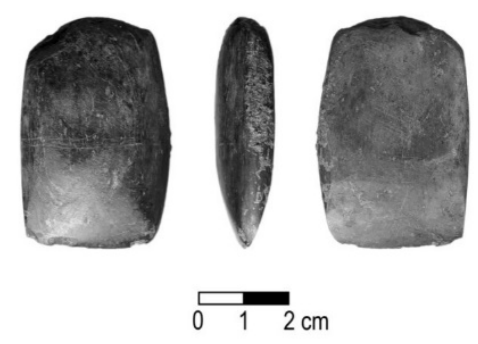

3

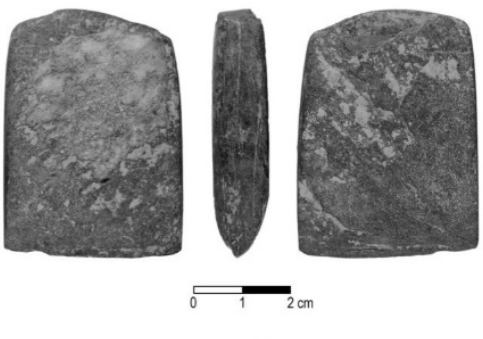

6

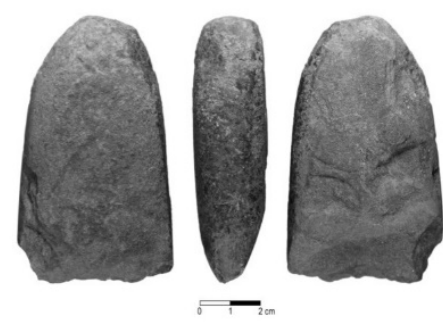

9
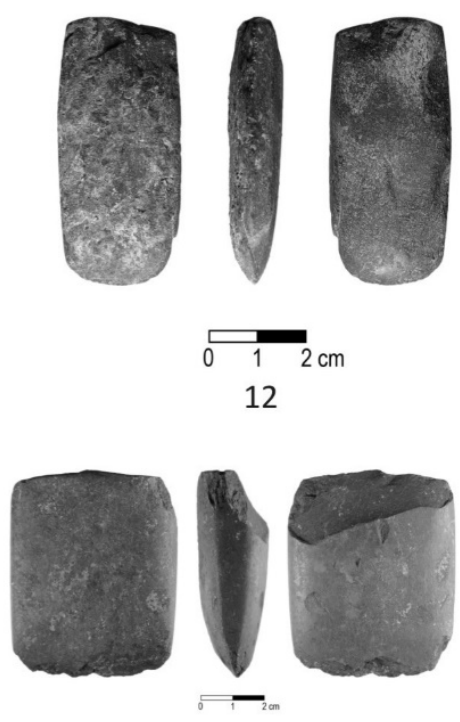

15

Plate IV. Adzes. 

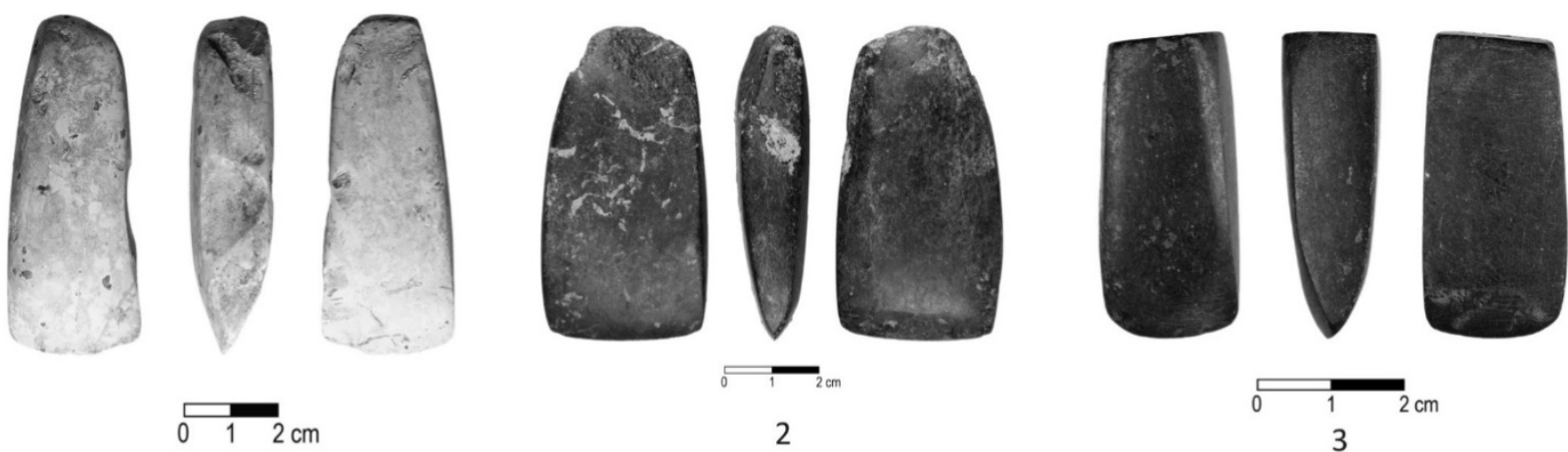

2

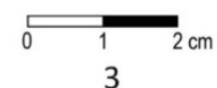

1
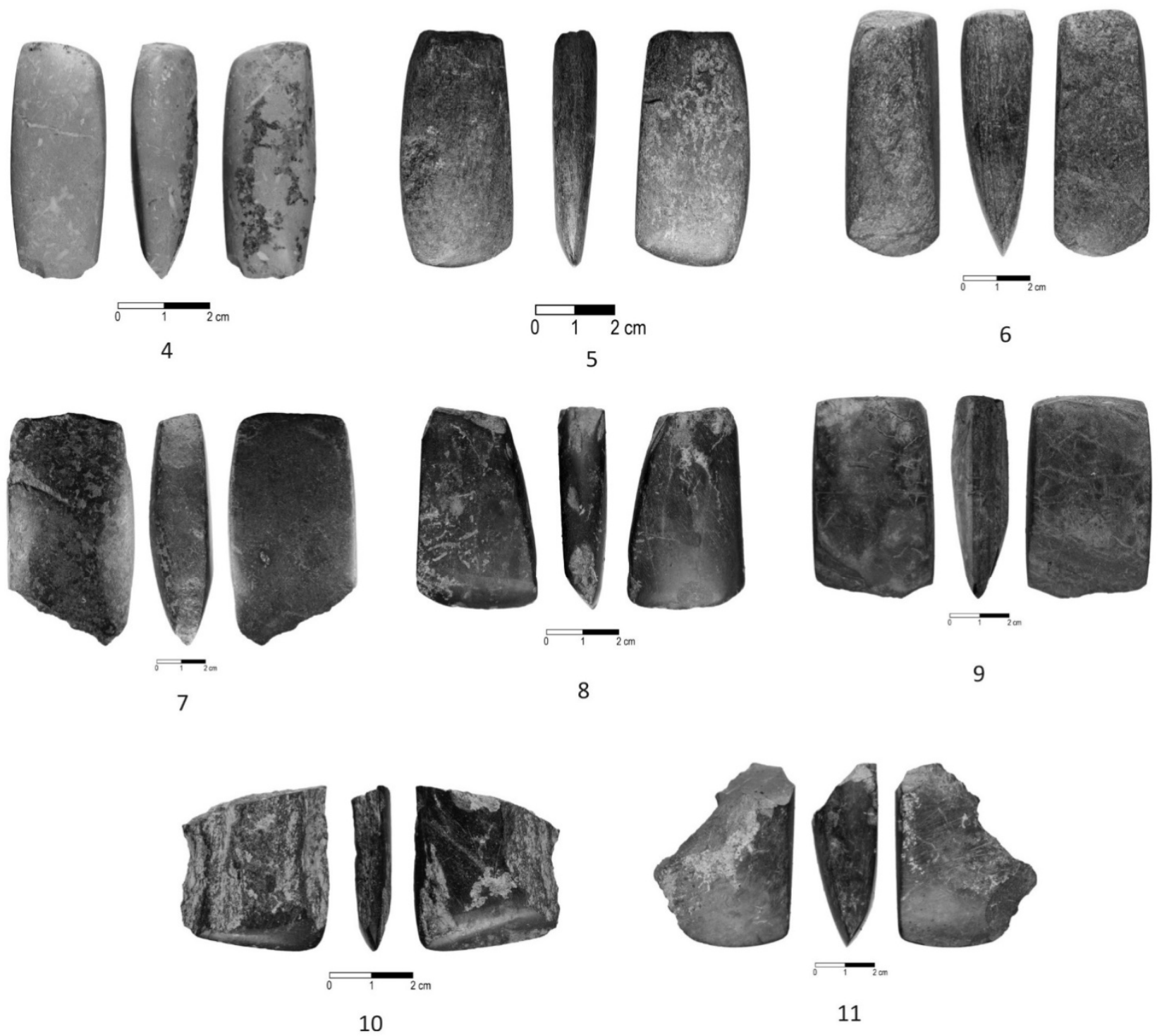

11

Plate V. Adzes. 



Plate VI. Chisels. 


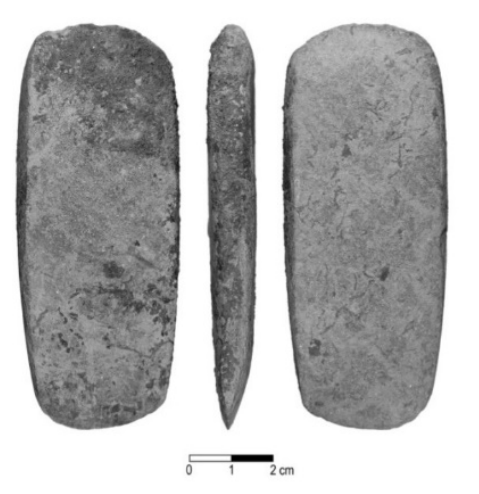

1

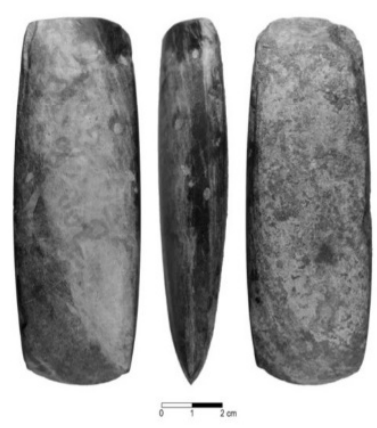

4
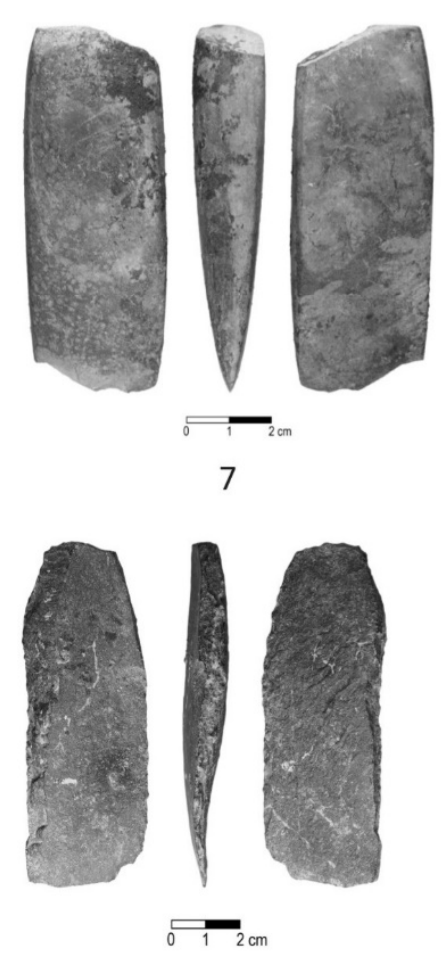

10
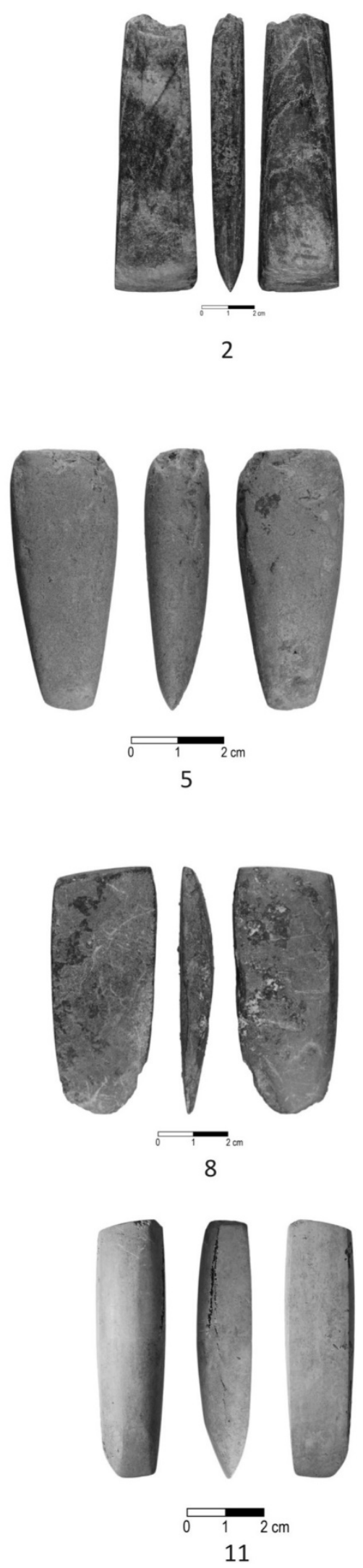

Plate VII. Chisels.

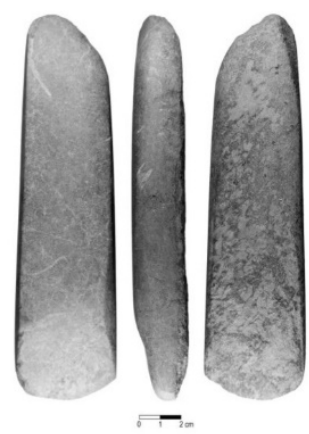

3
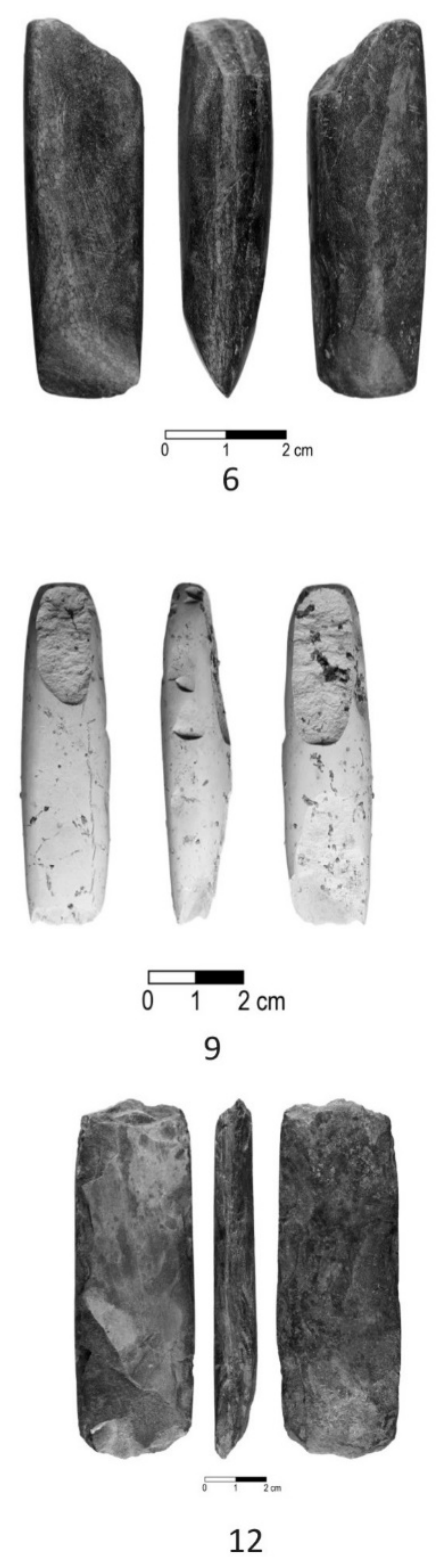


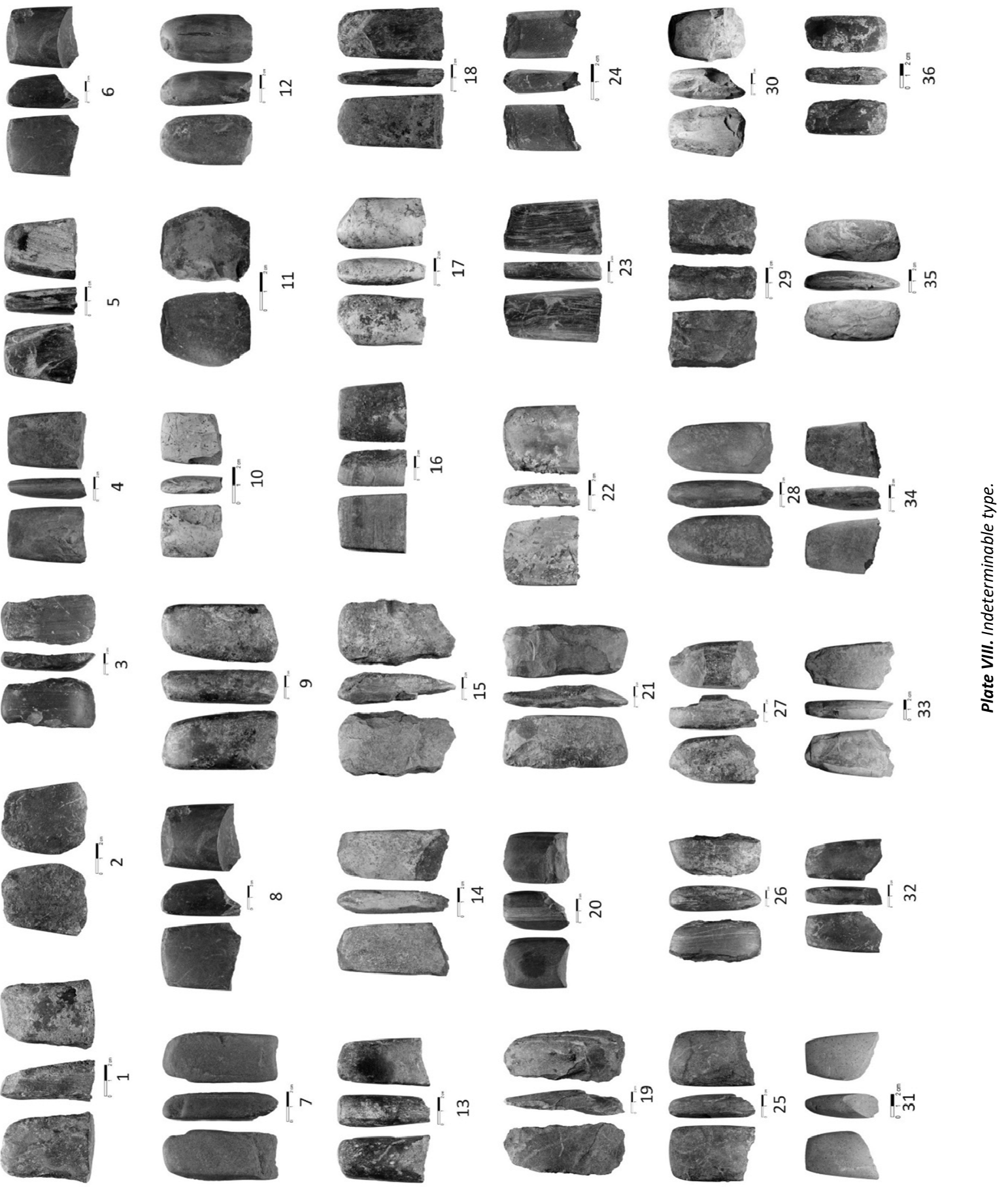



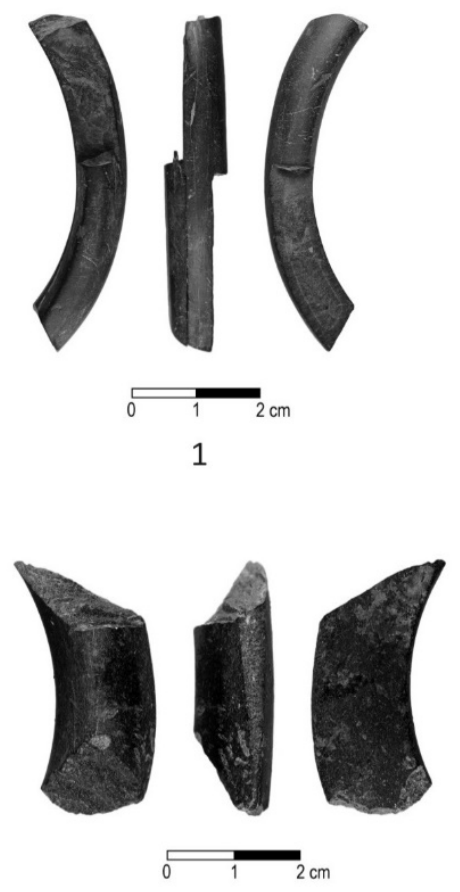

4

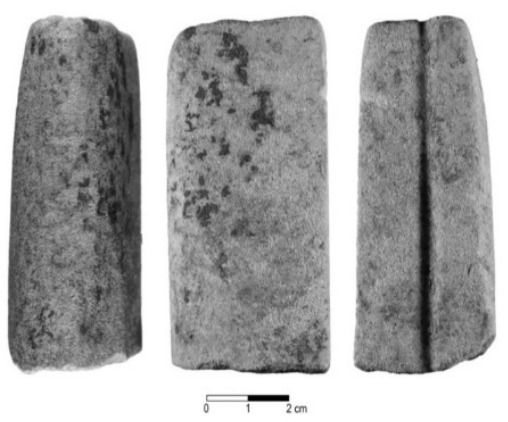

7

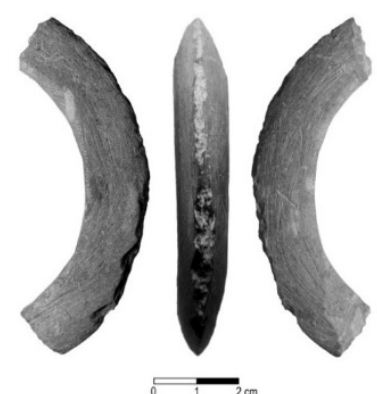

2

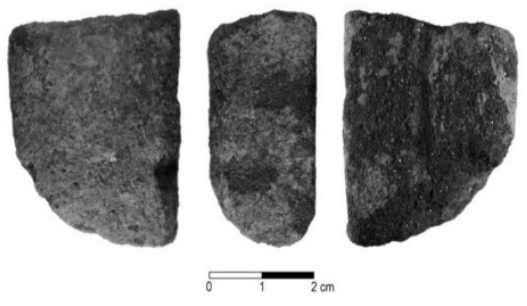

5
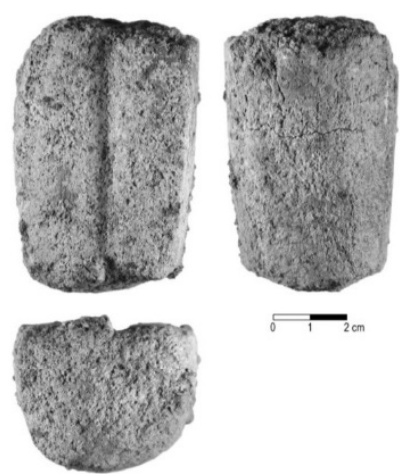

8

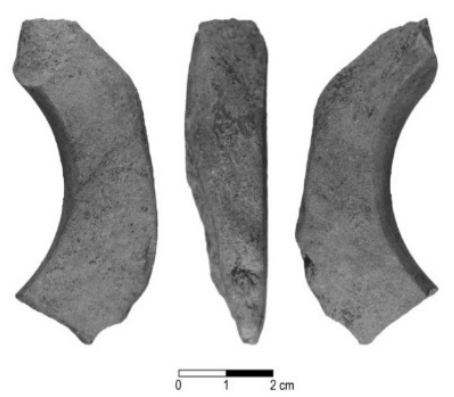

3

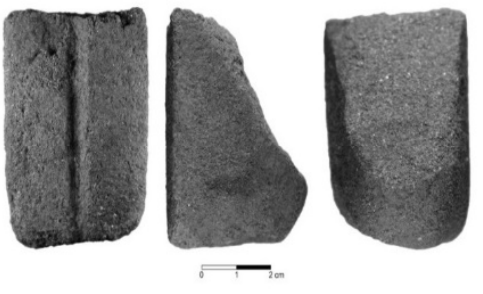

6

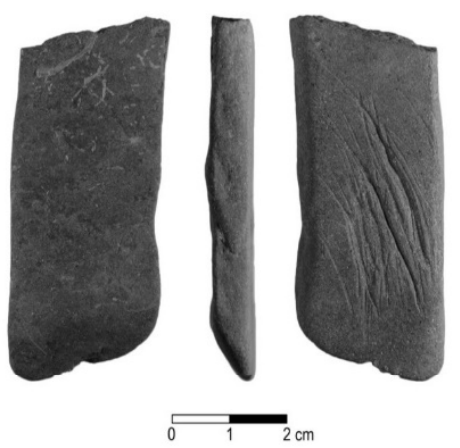

9
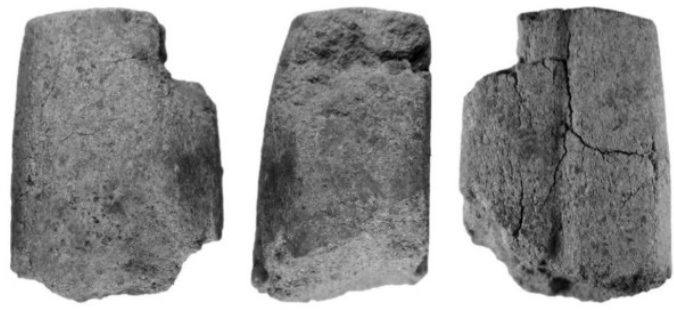

10

Plate IX. 1-4. Bracelets; 5-10. Polishers. 

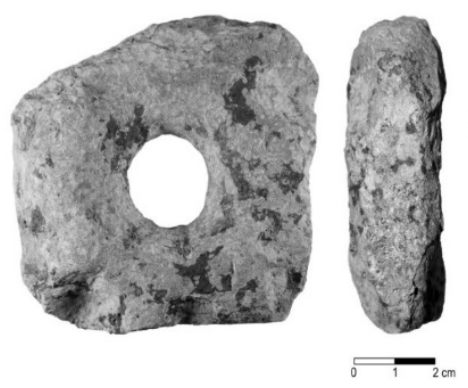

1
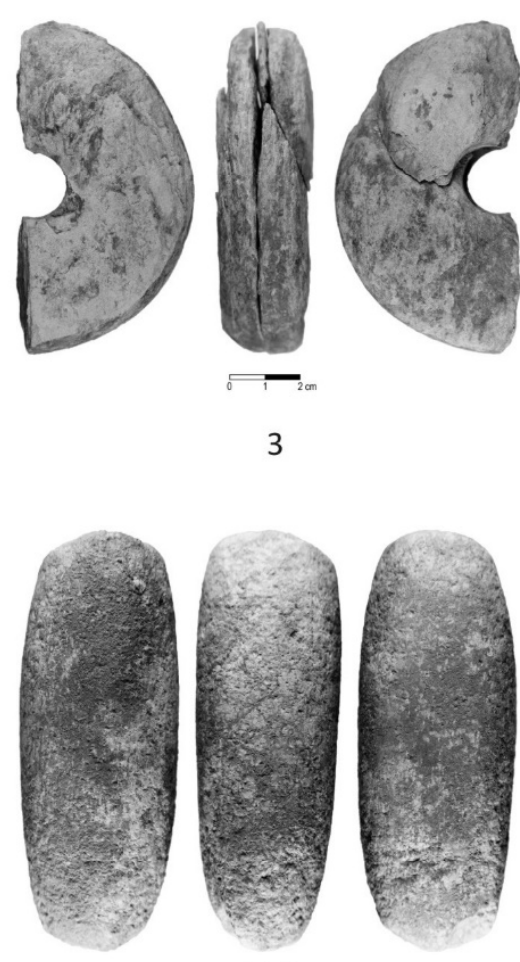

6

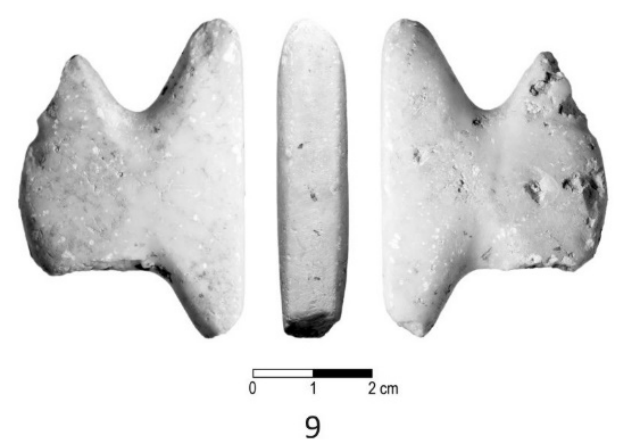

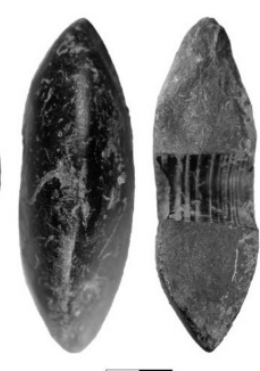

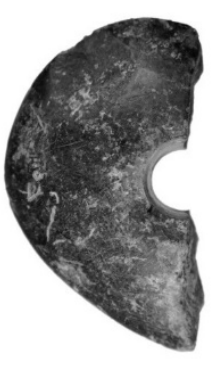

2

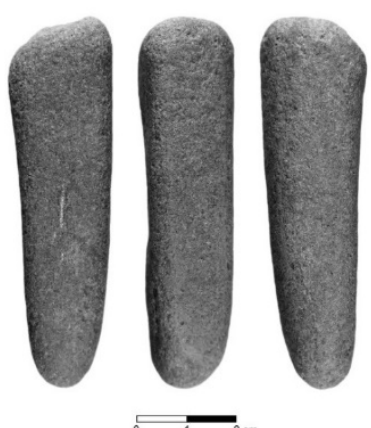

5

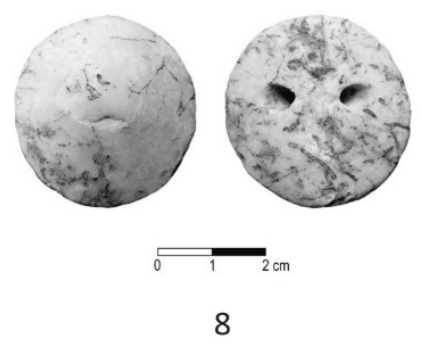

7
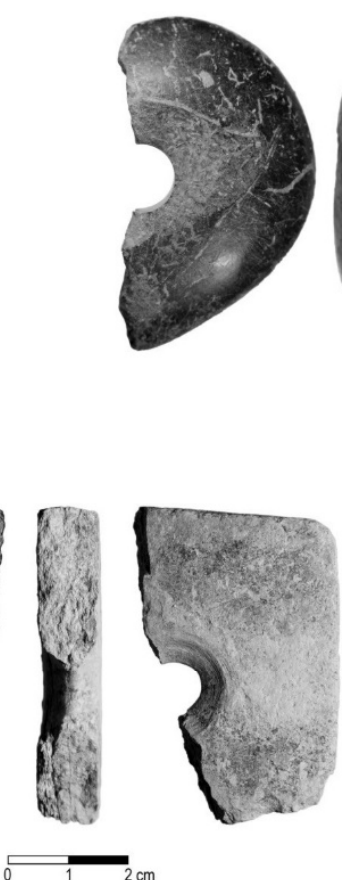

4

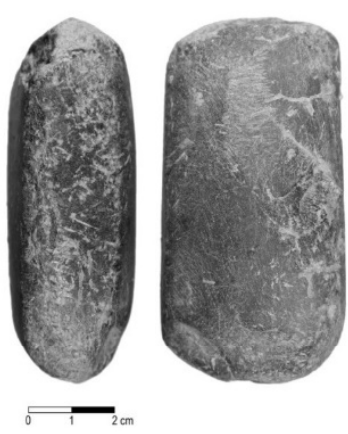

Plate X. 1-4. Perforated items; 5. Grinding mortar; 6, 7. Bolts; 8. Button; 9. Shuttle; 10. Mace head. 



\section{ABRÉVIATIONS / ABBREVIATIONS / ABREVIERI}

AA - Archäologischer Anzeiger. Deutsches Archäologisches Institut, Darmstadt, München, Tübingen-Berlin

Acta MN - Acta Musei Napocensis Cluj-Napoca

ActaMP - Acta Musei Porolissensis, Zalău

AJA - American Journal of Archaeology, Boston

Altertum - Das Altertum, Deutsche Akademie der Wissenschaften zu Berlin Sektion für Altertumswissenschaft

Akademie der Wissenschaften der DDR Zentralinstitut für Alte Geschichte und Archäologie, Berlin

AnB - Analele Banatului, Muzeul Banatului, Timişoara

Antiquity - Antiquity. A Review of World Archaeology, Durham, UK

ArchBulg - Archaeologia Bulgarica, Sofia

AIGR - Anuarul Institutului Geologic al României, Bucureşti

AllA Cluj - Anuarul Institutului de Istorie şi Arheologie, Cluj-Napoca

AM - Mitteilungen des Deutschen Archäologischen Instituts, Athenische Abteilung

Apulum - Acta Musei Apulensis. Muzeul Naţional al Unirii, Alba Iulia

ArchKorr - Archäologisches Korrespondenzblatt, Mainz

Argesis - Argesis. Muzeul Judeţean Argeş. Piteşti

ArhMold - Arheologia Moldovei, laşi

BA - Biblioteca de Arheologie, Bucureşti

BAI - Bibliotheca Archaeologica lassiensis, lași

BARIntSer - British Archaeological Reports. International Series, Oxford

BCȘS - Buletinul Cercurilor Științifice Studențești. Arheologie - Istorie - Muzeologie, Alba-lulia

BICS - Bulletin of the Institute of Classical Studies of the University of London, London

$\mathrm{Bjb}$ - Bonner Jahrbücher des Rheinischen Landesmuseums in Bonn, Bonn

BMA - Bibliotheca Memoriae Antiquitatis, Piatra-Neamţ

BMJT - Buletinul Muzeului Judeţean Teleorman, Alexandria

BMMN - Buletinul Muzeului Militar Naţional, Bucureşti

BMTA Giurgiu - Buletinul Muzeului „Teohari Antonescu”, Giurgiu

BPS - Baltic-Pontic Studies, Poznań

Britannia - Britannia. A Journal of Roman-British and Kindred Studies. Society for the Promotion of Roman Studies, Cambridge

BSA - British School at Athens, Athens

BSPF - Bulletin de la Societé Préhistorique Française, Paris

CA - Cercetări Arheologice, Bucureşti

Carpica - Carpica. Complexul Muzeal „Iulian Antonescu” Bacău, Bacău

Carst - Cercetare, explorare, Actualitatea speo, Recenzii, editorial, Știință, Tehnică, Cluj-Napoca

CCA - Cronica Cercetărilor Arheologice din România, Bucureşti

CCDJ - Cultură şi Civilizaţie la Dunărea de Jos, Călăraşi

CEFR - Collection de l'École Française de Rome

Cerclst - Cercetări Istorice, laşi

Dacia - Dacia (Nouvelle Série). Revue d'archéologie et d'histoire ancienne. Académie Roumaine. Institut d'archéologie "V. Pârvan », Bucarest

Documenta Praehistorica - Documenta Praehistorica, University of Ljubljana, Faculty of Arts, Department of Archaeology

EphemNap - Ephemeris Napocensis. Academia Română, Institutul de Arheologie şi Istoria Artei, Cluj-Napoca

ERAUL - Études et Recherches archéologiques de l'Université de Liège

ÉtThas - Études thasiennes, École Française d'Athènes, Athènes-Paris

EurAnt - Eurasia Antiqua. Deutsche Archäologisches Institut, Berlin

GodișnikSofia - Godişnik na Sofijaskija Universitet „Sv. Kliment Ochridski”, Istoriceskij fakultet, Sofia

Hesperia - Hesperia. Journal of the American School of Classical Studies at Athens, Cambridge

IFAO - Institut français d'archéologie orientale, le Caire

JAS - Journal of Archaeological Science 
Kernos - Revue internationale et pluridisciplinaire de religion grecque antique, Liège Marisia - Marisia. Studii şi materiale. Arheologie - Istorie - Etnografie, Târgu Mureş MemAnt - Memoria Antiquitatis, Piatra Neamţ MCA - Materiale şi Cercetări Arheologice, Bucureşti

OLBA - Mersin University Publications of the Research Center of Cilician Archaeology, Mersin, Turkey

Paléo - Paléo. Revue d’Archéologie Préhistorique, Les Eyzies, France

Peuce - Peuce, Studii şi cercetări de istorie şi arheologie, Institutul de Cercetări Eco-Muzeale, Tulcea

Pontica - Pontica. Studii şi materiale de istorie, arheologie şi muzeografie, Muzeul de Istorie Naţională şi Arheologie Constanţa

Quartär - International Yearbook for Ice Age and Stone Age Research

RCRFActa- Rei Cretariae Romanae Fautorum

RE - Realenzyklopädie: Paulys realenzyklopädie der klassischen Altertumswissenschafts, Stuttgart, 1893

RI - Revista Istorică. Academia Română, Institutul de Istorie „Nicolae lorga”, Bucureşti

RESEE - Revue des Études Sud-Est Européennes. Academia Română, Institutul de Studii Sud-Est Europeene, Bucureşti RevBistr - Revista Bistriței. Complexul Muzeal Bistriţa-Năsăud, Bistriţa

SAA - Studia Antiqua et Archaeologica, laşi

$\operatorname{SCIV}(A)$ - Studii şi Cercetări de Istorie Veche (şi Arheologie), Bucureşti

SlovArch - Slovenská Archeológia, Nitra

SMMIM - Studii și Materiale de Muzeografie și Istorie Militară, București

SP - Studii de Preistorie, Bucureşti

Suceava - Suceava. Anuarul Muzeului Bucovinei, Suceava

Th-D - Thraco-Dacica, București

Transylvanian Review - Transylvanian Review. Centrul de Studii Transilvane, Cluj-Napoca

Tyragetia - Tyragetia. Anuarul Muzeului Naţional de Istorie a Moldovei, Chişinău

VT - Vetus Testamentum 